\title{
Public Opinion and Executive Compensation
}

\author{
Camelia M. Kuhnen \\ Department of Finance, Kellogg School of Management, Northwestern University, \\ Evanston, Illinois 60208, c-kuhnen@kellogg.northwestern.edu \\ Alexandra Niessen \\ Department of Finance, University of Mannheim, Mannheim 68167, Germany, niessen@bwl.uni-mannheim.de
}

\begin{abstract}
W e investigate whether public opinion influences the level and structure of executive compensation. During 1992-2008, the negativity of press coverage of chief executive officer (CEO) pay varied significantly, with stock options being the most criticized pay component. We find that after more negative press coverage of CEO pay, firms reduce option grants and increase less contentious types of pay such as salary, although overall compensation does not change. The reduction in option pay after increased press negativity is more pronounced when firms, CEOs, and boards have stronger reputation concerns. Our within-firm, within-year identification shows the results cannot be explained by annual changes in accounting rules regarding executive compensation, stock market conditions, or pay mean reversion.
\end{abstract}

Key words: executive compensation; public opinion; media coverage

History: Received January 13, 2011; accepted October 26, 2011, by Brad Barber, finance. Published online in Articles in Advance February 28, 2012.

\section{Introduction}

Public opinion, as channeled by the news media, has been shown to be a disciplining device for corporate decisions. It shapes aspects of corporate governance such as the treatment of minority shareholders (Dyck and Zingales 2002, Dyck et al. 2008) or board independence (Joe et al. 2009), and it is important in the detection of corporate fraud (Miller 2006). In the context of executive pay, Bebchuk et al. (2002) and Bebchuk and Fried (2004) argue that public outrage may constrain chief executive officer (CEO) compensation. In addition, Weisbach (2007) suggests that firms may camouflage executive compensation by having it take forms that are typically not discussed in the press, thereby avoiding public attention. This paper investigates empirically whether general public opinion about certain pay practices indeed has an impact on the level and structure of CEO pay.

Anecdotal evidence suggests that public opinion does matter. For example, in 2003, Pearl Meyer and Partners, a compensation consultancy, stated that stock options had recently been "absolutely crucified" and were seen by the public as "the root of all evil." As a result, the consultancy argued, boards ratcheted up restricted stock compensation to avoid optionbased pay. ${ }^{1}$ Also, some prominent CEOs concerned about public opinion declined some or all of their

\footnotetext{
${ }^{1}$ See Anderson (2003). Similarly, in 2009 the Wall Street Journal quoted compensation experts from the law firm Jones Day, saying that the public anger has "given boards the backbone to write
}

promised option grants in response to public outrage. ${ }^{2}$ Recently, Goldman Sachs acknowledged that public anger about high executive compensation constrained the pay of its top five executives in 2009 (Farrell 2009).

Survey data also indicates that in the last few decades the U.S. public has become more averse to income inequality (McCall 2003) and is now critical of CEO compensation (Page and Jacobs 2009). For example, Page and Jacobs (2009) find that although Americans think income inequality is necessary to motivate hard work, $75 \%$ of those polled believe that inequality has become too high and certain jobs are overpaid. Survey respondents also favor a reduction of CEO pay. The recent "Occupy Wall Street" movement also illustrates the public concern regarding income distribution in society. It remains an open question, however, whether public negativity toward income inequality, and specifically toward executive pay, is in fact a factor determining firms' compensation policies.

In this paper we provide empirical evidence that firms take public opinion into account when deciding the composition of CEO pay and that this effect is

stricter standards on pay. ... People talk about how angry their own friends and families are. ... Boards are thinking: Try to get your act together before the government is there to help you" (see Dvorak 2009)

${ }^{2}$ For example, Bradbury Anderson at Best Buy in 2003 and James Wells at SunTrust Banks in 2008 (see Lublin 2005, Beck and Fordahl 2009). 
driven by reputation concerns. Firms value reputation because it is a signal of product quality (Milgrom and Roberts 1982) and a determinant of financial performance (Michalisin et al. 2000, Roberts and Dowling 2002). Managers and directors seek to maximize their personal reputation to succeed in later career moves and to avoid being perceived as "bad guys" (Dyck and Zingales 2002). Firms and their leaders may therefore want to protect their reputation by setting pay in a way that does not upset the public.

An added benefit of avoiding negative public opinion may be to reduce the odds of populist political interventions that can put further constraints on CEO pay (Jensen and Murphy 1990). According to Culpepper (2010), the more the public cares about an issue, the more likely it is that this issue catches the attention of politicians and creates an incentive for them to act, which can explain for example the rise of executive pay to political prominence in 1992. After Business Week published an article titled "Are CEOs Paid Too Much?" (Byrne 1991), Senator Carl Levin and President Bill Clinton suggested legislation to regulate CEO pay. This created pressure on the Securities and Exchange Commission and led to the passing of new rules constraining CEO compensation in 1993. High political salience, however, does not always result in more regulation; for example, shareholder "say on pay" proposals were defeated in Congress twice, in 2005 and 2007. Nonetheless, the potential threat of regulatory intervention may induce firms to react preemptively to avoid legislative action.

Here we measure public opinion by analyzing the text of all newspaper articles on executive compensation published in the United States during 1990-2010 using computer linguistic software as in Tetlock (2007), Tetlock et al. (2008), and Loughran and McDonald (2010). We quantify the tone of each article and compute an aggregate measure of negativity toward CEO pay. Whereas media coverage reflects current public opinion, it can also influence future public attitudes (Herbst 1998). Therefore, our measure of negativity toward executive pay expressed in newspaper articles is an imperfect measure of the public's view concerning CEO compensation. However, because of the lack of surveys or polls that consistently ask for the public's attitude on this topic, the tone of press coverage of executive pay is our best available measure of public opinion. ${ }^{3}$

\footnotetext{
${ }^{3}$ The General Social Survey (GSS) funded by the National Science Foundation, although not directly addressing executive compensation, includes a variable ("EQWLTH") that measures the fraction of respondents who think that the government should reduce income differentials. One would expect a positive correlation between our newspaper-based measure of negativity regarding CEO pay and the GSS measure of public dislike of income inequality. Indeed,
}

We find that the negativity of coverage of executive compensation in the U.S. press varies substantially over time, with the most criticized pay component being stock options. The public focus on options during our sample may be due to regulation passed in 1993, which limited the corporate tax deduction of non-performance-based executive compensation to $\$ 1$ million per year. This might have spurred the use of option-based pay (not treated as an expense until rule FAS 123(R) was passed in 2004), whose high valuations might have caused public outrage.

We relate compensation data for the period 1992 2008 to our negativity measure and show that options pay decreases significantly following strong criticism of CEO pay in the press. At the same time, we observe an increase in types of pay that receive less media attention, such as salary, bonus, and restricted stock. Press negativity does not significantly influencethe total level of CEO pay but alters its composition. Payto-performance sensitivity (PPS) diminishes following increases in press negativity, more so in poorly governed firms. Consistent with reputation concerns driving our results, we find that the shift away from options in response to press negativity is stronger for firms that are more in the public eye; those that have less entrenched and younger CEOs, who have stronger career concerns (Gibbons and Murphy 1992, Bebchuk and Fried 2004); and those with more independent and less busy boards.

Overall, our results indicate that the composition of pay reacts to press negativity in a way that suggests that firms prefer to avoid using the type of pay that is most publicly contested. When using annual compensation data from Execucomp, the results are robust to including firm fixed effects, lagged values of pay, controls for overall economic conditions, as well as other firm-year controls typically used in prior research on executive compensation. Nevertheless, it is still possible that omitted year-specific factors such as the aforementioned regulation changes in 1993 and 2004 are correlated with both the prior year's negativity of press coverage and the values of different types of pay. The former change likely caused firms to increase the usage of options after 1994 (Rose and Wolfram 2002), whereas the latter led firms to shift compensation from option grants to restricted stock awards after 2005 (Carter et al. 2007, Hayes et al. 2012). Another concern is that the timing of option and stock awards is not fully exogenous. For instance, it could be that bad stock market performance drives

we find these two variables are positively correlated. Nonetheless, because the GSS measure is only constructed every two years and does not measure public attitudes specifically about executive pay, in this paper we use the tone of media coverage as our proxy for public opinion regarding $\mathrm{CEO}$ compensation. 
both the public negativity about CEO pay and the timing (and size) of subsequent option awards that firms offer to their executives.

Our identification strategy to address these concerns is twofold. First, we account for dynamic endogeneity in the determination of pay and press coverage and isolate the causal effect of prior press negativity on subsequent pay by estimating a system generalized method of moments (GMM) model. Second, we take advantage of exogenous variations in firms' fiscal year ends using data from the Thomson Reuters Insider Filings database. This database provides the number and the exact date of options and shares of stock granted to CEOs, at the firmgrant level. In contrast to the Execucomp annual data, the Thomson data allow us to include firm, calendar month and year fixed effects, and to test within firm whether within-year differences in the negativity of CEO coverage in the press in the months prior to the grant in fact influence the value of the grant. We repeat our analysis using only the option grants made by boards after the firm's fiscal year end during regularly scheduled meetings, whose timing is exogenous to concurrent events. In this subsample of exogenously timed grants, we observe a similar effect as in the main sample: higher press negativity regarding CEO pay reduces the value of option grants and increases the value of stock grants. The effect of negativity is even stronger in this subsample of grants than in the overall sample.

Our results complement and help interpret the findings of two extant papers that study whether firms change CEO pay in response to negative press coverage. Johnson et al. (1997) found that after a negatively toned article about a specific firm in leading U.S. newspapers there was a smaller subsequent increase in the pay of that firm's CEO. Core et al. (2008) argued that this captures a mechanical pay mean-reversion effect and not the firms' response to press coverage. They documented that CEOs that draw negative media attention after receiving excessive compensation are more likely to get lower pay later, but the relation between media coverage and subsequent pay is not causal. The authors showed that, controlling for a firm's lagged CEO pay, the amount of negative publicity regarding that particular firm does not predict the value of the CEO's future compensation. Importantly, both these papers ask whether firmspecific press coverage leads to a change in the level of CEO pay. Our approach differs from theirs in several important ways. First, we look at the level and the composition of pay, because Weisbach (2007) suggests that firms may react to public opinion by changing the types of pay offered but not its level. Our results support this view because they show that the composition of pay changes in response to press negativity, whereas the level of pay does not react. Second, we analyze nationwide public negativity, as reflected in a large number of newspaper articles, instead of focusing on firm-specific press coverage. It is likely that stronger waves of public opinion may be needed for boards to think about CEO pay, rather than a few articles about individual firms. ${ }^{4}$ Third, we investigate whether there is heterogeneity across firms in their response to press negativity. For example, it is possible that firms with egregious CEO pay may be poorly governed and therefore unlikely to respond much to public concerns. In other words, public opinion may have less influence on more entrenched managers or boards, a prediction consistent with our crosssectional results.

This paper contributes to two strands of the literature. First, we add to the small but growing literature on the impact of media and public opinion on corporate decisions (e.g., Dyck and Zingales 2002, Core et al. 2008, Dyck et al. 2008, Joe et al. 2009) by analyzing the effect of widespread public opinion on the composition of CEO pay. Second, we contribute to the literature on executive compensation and corporate governance (e.g., Murphy 1999, Core et al. 1999, Holmstrom and Kaplan 2003, Bebchuk and Fried 2004, Kuhnen and Zwiebel 2007) by providing evidence that public outrage can change the composition of executive pay. Thus, public opinion may change the CEOs' incentives and behavior, and ultimately shape firm outcomes.

\section{Data}

We use several databases described below to obtain public opinion measures, CEO pay variables, and firm characteristics. We summarize the relevant data items in Table 1.

We measure widespread public opinion regarding $\mathrm{CEO}$ pay by quantifying the tone of newspaper articles on executive compensation published during 1990-2010 in U.S. newspapers covered by the Factiva news database. These are articles that contain at least one of the following keywords: "CEO compensation," "CEO salary," "CEO pay," "executive compensation," "executive salary," or "executive pay." Our search yielded 26,123 articles on executive compensation. Each article related to CEO pay was classified by source, date, state in which the newspaper was published, and whether it was a national or state-level publication. National newspapers were those labeled as such in the U.S. Department of Interior's Pro Quest Database (i.e., the New York Times, USA Today, the Wall Street Journal, the Financial Times, the Washington Post,

\footnotetext{
${ }^{4}$ Illustrating this point, the Washington Post suggested that a "tidal wave of public outrage" influenced pay decisions at AIG in 2009, as directors and managers were intimidated by death threats and angry letters from the public (Dennis and Cho 2009, p. A01).
} 
Table 1

\section{Description of Variables}

Variable

AnalystCoverage CEOIsUnder60,

GovernanceConcerns

Elndex $x_{t}$

EmployeeConcerns $_{t}$

ExcessPay

LMNegativity

StateNegativity $_{t}$

MarketValue

NBER_Recession

NationalNegativity

NationalNegativity $_{m-3, m-1}$

NationalNegativity $_{m-6, m-1}$ Options

Options $_{m}$

OptionSensitivity

OptStockSensitivity ${ }_{t}$

OtherPay,

Ownership

PayTypeCoverage

(e.g., OptionsCoverage)

ProductSafetyConcerns ${ }_{t}$

$R O A_{t}$

Salary + Bonus

Sales

SalesGrowth

CompensationProposal ${ }_{t}$

SP500RET $_{t}$

StockRet $_{t}$

Stock ${ }_{t}$

Stock $_{m}$

StockSensitivity

TotalCompensation $_{t}$

Volatility $_{t}$

Irregularity $_{t}$

$B B 1_{t}$

$B B 2_{t}$

$B B 3_{t}$

majind $_{t}$

CCind $_{t}$
Definition

Number of analyst forecasts of earnings per share. Source: I/B/E/S.

Dummy variable equal to one if CEO's age is $<60$ years and zero otherwise. Sources: Execucomp, Factiva.

Number of corporate governance concerns. Source: KLD (item cgov_con_num).

Bebchuk et al. (2009) entrenchment index based on six shareholder rights measures. High values indicate weak governance.

Number of employee relation concerns. Source: KLD (item emp_con_num).

Excess total compensation in dollars computed as in Core et al. (2008).

Defined as NationalNegativity ${ }_{t}$ but using the dictionary in Loughran and McDonald (2010).

Defined as NationalNegativity ${ }_{t}$ but using state-level newspapers.

Market value of firm in \$millions. Source: CRSP/Compustat.

Dummy variable equal to one if economy in recession and zero otherwise. Source: NBER.

Average negativity in coverage of CEO pay in national newspapers in period $t$. Source: Factiva/LexisNexis, using LIWC 2007 and our own dictionary in Appendix A.

Average of NationalNegativity during the three months prior to the date of each option grant. Source: Thomson Reuters Insider Filings.

Defined similar to NationalNegativity ${ }_{m-3, m-1}$ but over the six months prior to the grant date.

Black-Scholes value of options granted in year $t$ (\$thousands). Source: Execucomp (items blk_valu and option_awards_fv).

Black-Scholes value of individual option grants used in monthly analysis. Source: Thomson Reuters Insider Filings.

Performance sensitivity of options computed as in Hartzell and Starks (2003).

Sum of OptionSensitivity ${ }_{t}$ and StockSensitivity ${ }_{t}$ (Babenko 2009).

TotalCompensation $_{t}$ - Salary - Bonus - Options $_{t}-$ Stock $_{t}$

Shares owned by CEO divided by shares outstanding. Source: Execucomp (item shrown_excl_opts)/Compustat (item csho).

Fraction of words in an article that refer to the specific type of pay. Source: Factiva/LIWC 2007, keywords in Appendix B.

Number of product safety concerns. Source: KLD (item pro_con_a)

Return on assets of firm. Source: Execucomp (item roa).

Salary and bonus in year $t$ (\$thousands). Source: Execucomp (items salary and bonus).

Firm sales in \$millions. Source: CRSP/Compustat

Sales growth of firm (\%). Source: Execucomp (item salechg).

Dummy variable equal to one if compensation proposal submitted to firm in year $t$ and zero otherwise. Source: IRRC.

Annual S\&P 500 return. Source: CRSP/Compustat.

Annual stock return of firm. Source: CRSP/Compustat.

Value of stock grants in year $t$ (\$thousands). Source: Execucomp, using Walker (2009) adjustment.

Value of individual stock grants used in monthly analysis. Source: Thomson Reuters Insiders Filings.

Performance sensitivity of stock awards, as in Babenko (2009).

Total pay in year $t$ (\$thousands). Source: Execucomp (item $t d c 1$ ).

Annualized firm stock return standard deviation. Source: CRSP.

Dummy variable equal to one if accounting irregularity at firm in year $t$ according to Hennes et al. (2008) and zero otherwise.

Average number of directorships per director. Source: IRRC.

Maximum number of directorships per director. Source: IRRC.

Percentage of directors with three or more directorships. Source: IRRC.

Dummy variable equal to one if majority of board members is independent (median cutoff) and zero otherwise. Source: IRRC.

Dummy variable equal to one if majority of compensation committee is independent (median cutoff) and zero otherwise. Source: IRRC. and Barron's). Of all articles, 6,982 are classified as national and 19,141 as state level.

To quantify the tone of each article, we use the Pennebaker et al. (2007) linguistic inquiry and word count (LIWC) computer program, following the approach of prior papers concerned with textual analysis (Tetlock 2007, Tetlock et al. 2008, Loughran and McDonald 2010). The program automatically processes text files and analyzes their content based on an internal dictionary. When reading a random subsample of the articles, we noted that there are only a handful of positive articles about executive compensation.
This observation is in line with a negativity bias in the news media that has been documented before (e.g., Niven 2001). Thus, in our analysis, we focus on measuring the degree of negative (rather than positive) public opinion on CEO pay.

The program's default dictionary contains a category consisting of 499 words to measure negative emotions in general text. However, these words may not suitably capture the tone of articles covering executive compensation, because the wording of such articles is more specialized than that of general readings. For example, words such as "lavish" or "backdating" 
have a negative connotation in the context of a CEO pay discussion, but are not included in LIWC's default internal dictionary of negative words. Therefore, we use three alternative dictionaries to measure negativity toward CEO pay. First, we construct our own dictionary for characterizing the tone of newspaper articles on CEO compensation. We randomly drew 160 such articles, read them independently, and manually identified keywords (listed in Appendix A) reflecting emotions toward executive compensation. Our negativity dictionary contains these keywords and their grammatical variations (e.g., as singular and plural). Second, we use the dictionary developed by Loughran and McDonald (2010) to quantify the negativity of text in 10-K filings, because it is also explicitly designed for characterizing the tone of financial text. Third, we use the default dictionary of the computer linguistic program.

For each newspaper article we measure the negativity with respect to executive compensation as the percentage of words in the article that are among those that belong to each of the three negativity dictionaries. ${ }^{5}$ In the analysis, our main measure of public opinion toward CEO pay is captured by the variable NationalNegativity ${ }_{t}$ and is defined as the average negativity of all articles published in national newspapers during time period $t$, using our own negativity dictionary. The use of this measure is motivated by our conjecture that strong waves of public outrage are needed for firms to react. However, to alleviate concerns that our results are driven by time trends in compensation, in robustness checks we use the average negativity of CEO pay press coverage in the specific state of a firm's headquarters (StateNegativity ${ }_{i, t}$ ). The time period for which we compute the negativity measure is either a calendar year when we use the annual pay data from Execucomp, or a three- or sixmonth window prior to each month when CEOs in the sample receive stock or option grants according to the Thomson Reuters Insider Filings database.

Summary statistics in Table 2 show that the average negativity in a CEO pay-related article measured in either national or state-level newspapers is $1.5 \%$ using our CEO pay-specific dictionary and 1.85\% using the dictionary in Loughran and McDonald (2010). The correlation between an article's negativity defined using the negative word list in Loughran and

\footnotetext{
${ }^{5}$ Although the method of classifying the tone of text based on a specific dictionary is the most frequently used in the literature, it is not the only available technique. For instance, $\mathrm{Li}$ (2010) uses a naive Bayesian machine learning algorithm to classify the tone of statements in 10-K and 10-Q filings. Tetlock (2007) lists some drawbacks of this approach, e.g., the results produced are difficult to replicate, and the technique requires subjective classification by the econometrician of the tone of the text used as training data for the machine learning algorithm.
}

McDonald (2010) and its negativity according to our own dictionary is $0.63(p<0.01)$. There also is a significant positive correlation $(0.47, p<0.01)$ between an article's negativity defined using the default dictionary of the linguistic program and its negativity according to our own. Therefore, although articles on executive compensation have a slightly different wording than typical narratives, their tone is characterized in a similar way by our negativity measure and that based on the dictionary in Loughran and McDonald (2010). In the analysis, we will mainly use the national-level press negativity measured using our own dictionary that is specific to compensationrelated text.

We also examine how often various components of pay are mentioned in these articles by calculating the percentage of words in each article that refer specifically to each pay type (see Appendix B for the relevant keywords). For instance, to calculate the frequency with which salary is mentioned, we count how many times the word "salary" and its grammatical variations appear in an article and then divide that count number by the total number of words in the article.

CEO compensation data were obtained from two sources: Execucomp and Thomson Reuters Insiders Filings databases. We used both databases because they each have advantages and disadvantages for answering our research question. Execucomp has information about all types of pay during 1992-2008, but only at annual frequency, which makes it difficult to parse the effect of annual press negativity from that of other year-specific events, such as the change in the accounting treatment of options that took effect in 2006. Thomson only covers option and stock compensation, but has grant-level data, and therefore we have multiple observations of grants for the same firm occurring in the same year but facing different public negativity. Hence we are able to control for annual modifications in accounting rules or any other changes specific to the year that can drive both negativity and pay by estimating our effects with year, calendar month, and firm fixed effects.

Summary statistics in Table 2 are provided for annual compensation data from ExecuComp (panel A) and monthly compensation data from Thomson (panel B). From Execucomp we get annual values for the period 1992-2008 for the total pay awarded to CEOs of firms included in the S\&P 1500, as well as the value of each type of pay: salary, bonuses, option grants, stock grants, and other pay not included in the prior four components. The value of OtherPay includes items such as perquisites, personal benefits, deferred compensation and tax reimbursements and is calculated as TotalCompensation $t_{t}-$ Salary $_{t}-$ Bonus $_{t}-$ Options $_{t}-$ Stock $_{t}$. Variables Salary $t$ and Bonus $s_{t}$ 
Table 2 Summary Statistics

\begin{tabular}{|c|c|c|c|c|}
\hline & Mean & Std. dev. & Median & Observations \\
\hline \multicolumn{5}{|c|}{ Panel A: ExecuComp } \\
\hline TotalCompensation $_{t}$ (thousand $\$ s$ ) & $4,829.95$ & $10,910.50$ & $2,411.89$ & 19,658 \\
\hline Options $_{t}$ (thousand $\$ s$ ) & $1,870.98$ & $3,837.62$ & 596.82 & 19,697 \\
\hline Salary + Bonus $_{t}$ (thousand $\left.\$ s\right)$ & $1,347.92$ & $1,621.62$ & 948.16 & 20,028 \\
\hline Stock $_{t}($ thousand $\$ s)$ & 702.54 & $1,730.26$ & 0 & 19,810 \\
\hline OtherPay $_{t}($ thousand $\$ s)$ & 360.99 & $1,347.91$ & 59.76 & 19,812 \\
\hline ExcessPay $_{t}$ (thousand $\$ s$ ) & -0.07 & $9,626.87$ & -730.77 & 19,341 \\
\hline Ln( TotalCompensation $\left._{t}\right)$ & 7.82 & 1.16 & 7.79 & 19,658 \\
\hline $\operatorname{Ln}\left(\right.$ Options $\left._{t}\right)$ & 5.07 & 3.38 & 6.40 & 19,774 \\
\hline $\operatorname{Ln}\left(\right.$ Salary + Bonus $\left._{t}\right)$ & 6.84 & 0.98 & 6.85 & 20,031 \\
\hline Ln( OtherPay $\left._{t}\right)$ & 4.01 & 2.05 & 4.11 & 19,815 \\
\hline $\operatorname{Ln}\left(\right.$ Stock $\left._{t}\right)$ & 2.56 & 3.44 & 0 & 20,016 \\
\hline $\operatorname{Ln}\left(\right.$ ExcessPay $\left._{t}\right)$ & 0.00 & 0.91 & 0.02 & 19,583 \\
\hline NationalNegativity $_{t}(\%)$ & 1.53 & 0.11 & 1.51 & 20,031 \\
\hline StateNegativity $_{t}(\%)$ & 1.51 & 0.10 & 1.50 & 20,031 \\
\hline LMNegativity $_{t}(\%)$ & 1.85 & 0.22 & 1.91 & 20,031 \\
\hline OptionsCoverage (\%) & 0.24 & 0.57 & 0.00 & 6,982 \\
\hline SalaryCoverage (\%) & 0.16 & 0.32 & 0.00 & 6,982 \\
\hline BonusCoverage (\%) & 0.16 & 0.35 & 0.00 & 6,982 \\
\hline StockCoverage (\%) & 0.20 & 0.45 & 0.00 & 6,982 \\
\hline StockRet $_{t}$ & 0.19 & 0.52 & 0.12 & 20,031 \\
\hline$R O A_{t}$ & 0.04 & 0.10 & 0.04 & 20,031 \\
\hline SalesGrowth $_{t}$ & 0.12 & 0.24 & 0.09 & 20,031 \\
\hline Sales $_{t}($ million $\$ s)$ & $3,657.18$ & $6,810.35$ & $1,161.83$ & 20,031 \\
\hline MarketValue $_{t}($ million $\$ s)$ & $4,829.04$ & $10,479.29$ & $1,345.31$ & 20,031 \\
\hline $\operatorname{Ln}\left(\right.$ Sales $\left._{t}\right)$ & 7.20 & 1.54 & 7.10 & 20,031 \\
\hline $\operatorname{Ln}\left(\right.$ MarketValue $\left._{t}\right)$ & 7.42 & 1.57 & 7.30 & 20,031 \\
\hline Volatility $_{t}$ & 0.40 & 0.22 & 0.35 & 20,031 \\
\hline Elndex $_{t}$ & 2.46 & 1.32 & 2.50 & 20,031 \\
\hline$S P 500 R E T_{t}$ & 0.10 & 0.17 & 0.09 & 20,031 \\
\hline CEOIsUnder60 & 0.70 & 0.46 & 1.00 & 20,031 \\
\hline NBER_Recession ${ }_{t}$ & 0.19 & 0.39 & 0 & 20,031 \\
\hline OptionSensitivity $_{t}$ & 1.17 & 3.15 & 0.01 & 19,106 \\
\hline StockSensitivity $_{t}$ & 0.43 & 3.78 & 0.00 & 19,106 \\
\hline OptStockSensitivity $_{t}$ & 1.60 & 5.00 & 0.18 & 19,106 \\
\hline Ownership $_{t}$ & 0.05 & 0.08 & 0.01 & 19,106 \\
\hline CompensationProposal $_{t}$ & 0.03 & 0.32 & 0.00 & 17,252 \\
\hline \multicolumn{5}{|c|}{ Panel B: Thomson } \\
\hline Options $_{m}(\$ s)$ & 498,534 & $1,739,716$ & 79,959 & 92,536 \\
\hline $\operatorname{Ln}\left(\right.$ Options $\left._{m}\right)(\$ s)$ & 11.27 & 2.07 & 11.29 & 92,536 \\
\hline Stock $_{m}$ & 550,053 & 803,720 & 183,715 & 15,215 \\
\hline $\operatorname{Ln}\left(\right.$ Stock $\left._{m}\right)$ & 11.31 & 2.76 & 12.12 & 15,215 \\
\hline NationalNegativity $_{m-3, m-1}(\%)$ & 1.57 & 0.15 & 1.58 & 92,536 \\
\hline NationalNegativity $_{m-6, m-1}(\%)$ & 1.57 & 0.13 & 1.56 & 92,536 \\
\hline GovernanceConcerns & 0.54 & 0.62 & 0 & 68,449 \\
\hline EmployeeConcerns & 0.47 & 0.65 & 0 & 68,449 \\
\hline ProductSafetyConcerns $_{t}$ & 0.04 & 0.19 & 0 & 68,449 \\
\hline AnalystCoverage $_{t}$ & 56.59 & 52.95 & 42 & 88,463 \\
\hline Irregularity $_{t}$ & 0.33 & 0.47 & 0 & 3,825 \\
\hline$B B 1_{t}$ & 0.86 & 0.60 & 0.75 & 51,889 \\
\hline$B B 2_{t}$ & 2.67 & 1.69 & 3 & 51,889 \\
\hline$B B 3_{t}$ & 0.10 & 0.13 & 0.08 & 51,889 \\
\hline majind $_{t}$ & 0.53 & 0.49 & 1 & 65,514 \\
\hline cCind $_{t}$ & 0.59 & 0.49 & 1 & 64,835 \\
\hline
\end{tabular}

are given by Execucomp data items salary and bonus. The aggregate value of the stock options granted to the executive during the year $\left(\right.$ Options $\left._{t}\right)$ is computed using the S\&P Black-Scholes methodology and provided by data item blk_valu (or its post-2006 equivalent, option_awards_fv). As noted by Walker (2009), to obtain the values of the remaining pay variables we need to make certain adjustments to account for the fact that in 2006 Execucomp changed the way total compensation and the value of stock grants are reported. Specifically, before 2006 the data item $t d c 1$ was supposed to capture the total compensation given 
to the CEO that year, but in fact it did not measure the ex ante value of performance shares. To adjust

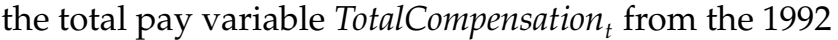
format to the new format, we first subtract the value of long-term incentive plans ltip (which measures the ex post value of performance shares) from $t d c 1$. Then, we extract the average stock price in the month were a firm grants most of its stock from the Thomson database. This stock price is then used to calculate the value of performance shares, which is added to $t d c 1$. For observations that could not be matched to Thomson data, we use the year-ending stock price in the adjustment of $t d c 1$. Similarly, the pre-2006 data item rstkgrnt (i.e., restricted stock) indicated the value of non-performance-contingent stock awards but not that of performance shares. For the period 2006-2008, a different data item, stock_awards_fo, measures all stock awards (i.e., restricted stock plus performance shares). We construct a comparable variable for the pre-2006 period by adding the value of performance shares to data item rstkgrnt. Our Execucomp-based data set consists of 20,031 firm-year observations during 1992 to 2008 and covers 3,081 unique firms.

From the Thomson Insiders Filings database we obtained the number of shares or options granted, the options' expiration date, and the dates when these grants were made for CEOs of publicly traded companies including those covered in Execucomp during 1992-2008 (we use only transactions referring to grants or awards pursuant to Rule 16b-3(c), i.e., those for which the Thomson Insiders Filings variable trancode equals " $\mathrm{A}$ "). We calculate the ex ante value (i.e., at the grant date) of option grants using the Black-Scholes formula, where, as inputs for dividend yield and volatility, we use the data items optdr and optvol from Compustat. The data set contains 107,751 individual option and stock grants given during 1996-2008 to CEOs of the firms covered in Execucomp, of which 92,536 are option awards and 15,215 are stock awards.

Last, we use Center for Research in Security Prices (CRSP)/Compustat for firm characteristics such as stock return or return on assets (ROA), Institutional Brokers' Estimate System (I/B/E/S) for the degree of analyst coverage, and KLD Research and Analytics for measures of concerns regarding each firm's corporate governance (e.g., whether the board allows excessive CEO compensation or the accounting standards at the firm are controversial), concerns regarding the relations between management and employees (e.g., whether the management ignores employee safety issues or has poor relations with the unionized workforce), and the existence of recent product safety concerns. CEO age was obtained from Execucomp, and when it was missing there (in about $10 \%$ of cases) we found it by reading Factiva news reports about the specific executive.

\section{Results}

\subsection{Negativity Toward CEO Pay in the Press}

Figure 1 shows the time series of multiple measures of negativity during 1990-2010 based on coverage in either national or state-level newspapers and using either our own dictionary, the one developed by Loughran and McDonald (2010), or the default one in the LIWC software. The annual aggregate values of each of these negativity measures are highly correlated, in line with the high correlations among articlelevel negativity measures that we documented earlier. By any measure, the negativity of CEO pay coverage is highest in years 1991-1992, 1996, and 2002-2003. For instance, in 2003 the NationalNegativity (according to our dictionary) is $1.73 \%$, more than one standard deviation higher than the sample mean of $1.53 \%$.

The data also show that in these articles the frequency of occurrence, as well as the negativity of coverage, differs significantly across the various types of executive pay, as seen in Figure 2. The left panel shows that during 1990-2008, the most discussed component was stock options, which accounted, on average, for $0.24 \%$ of the words in CEO pay articles in national newspapers. Salary and bonus terms each represented $0.16 \%$ of the article words, whereas stock awards accounted for $0.20 \%$. Furthermore, the right panel of Figure 2 shows that in every single year during 1990-2008, most of the negative words concerning CEO compensation $-45 \%$ on average - came from articles specifically mentioning option pay. In contrast, during the same time period, only $7 \%$ of all negative words in articles covering CEO compensation come

Figure 1 Mean Negativity in Newspaper Articles Discussing CEO Compensation

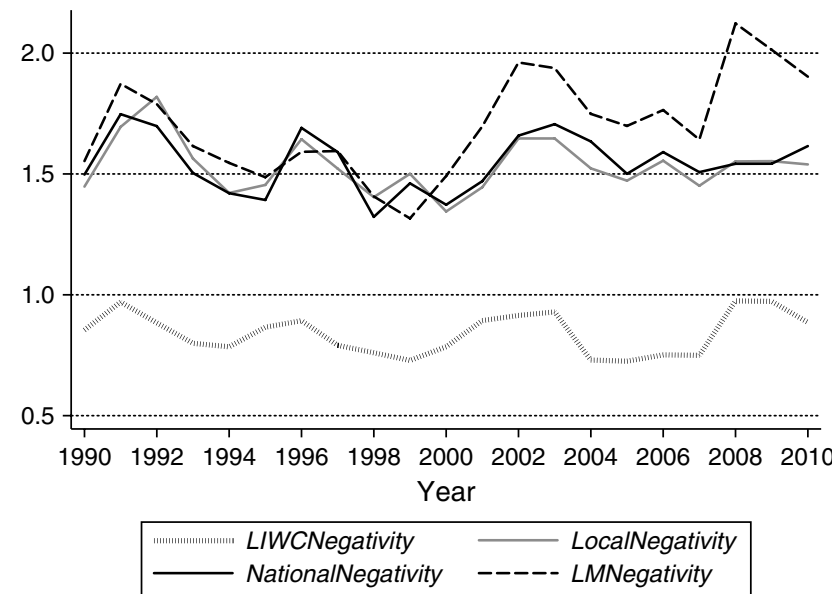

Note. NationalNegativity and LocalNegativity denote mean negativity in national and state-level newspapers, respectively, measured using our own negative word list (see Appendix A). LMNegativity and LIWCNegativity denote mean negativity in national newspaper articles measured using the list of negative words in Loughran and McDonald (2010) and the default list of negative words used by the LIWC linguistic software program, respectively. 
Figure 2 Mean Frequency of Coverage of Various Components of CEO Compensation in National Newspapers
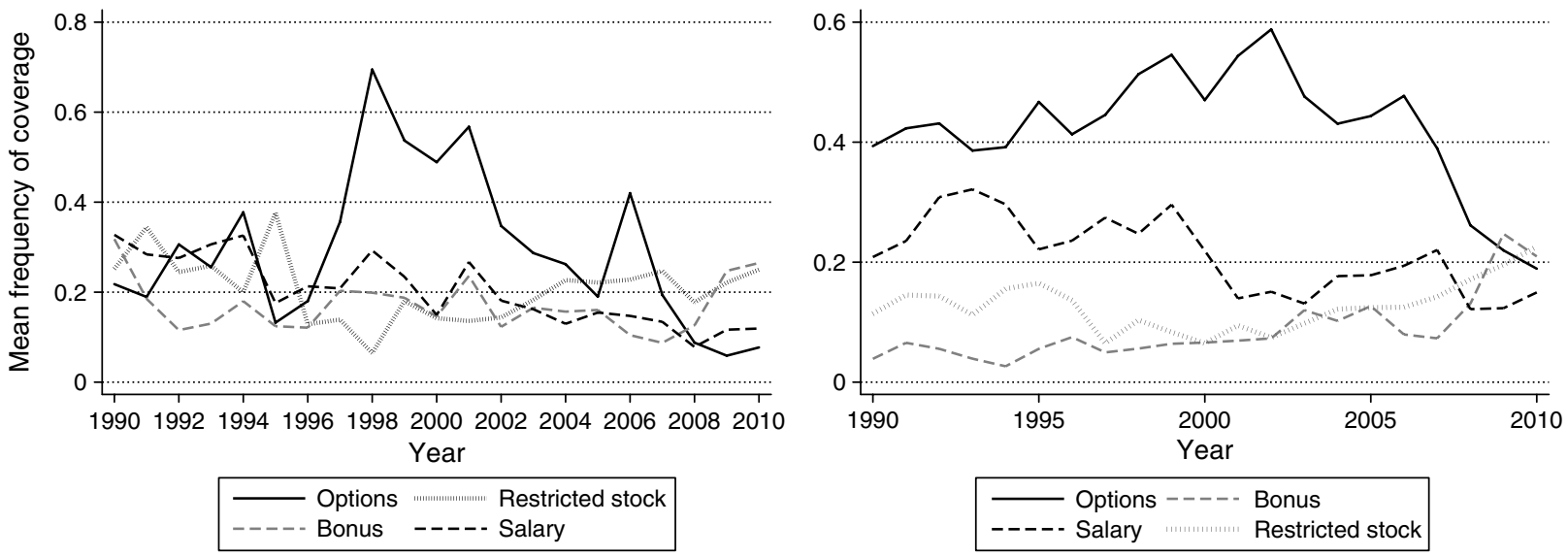

Notes. Left panel: The values on the $y$-axis represent the average percentage of words in CEO pay-related articles that refer to each pay component. For example, in 1998, on average, $0.7 \%$ of words in such articles in national newspapers referred to options pay (that is, they matched one of the keywords "option" or "backdating" listed in Appendix B, or their grammatical variations). Right panel: The values on the $y$-axis represent the percentage of all negative words in national newspaper articles covering CEO pay that come from articles covering each pay component. For example, in $2002,59 \%$ of all negative words about CEO pay came from articles specifically mentioning options.

from those specifically mentioning bonuses, for example. Two-sample mean comparison tests show that the frequency as well as the negativity of coverage of options are significantly higher than those of the other pay components $(p<0.001)$. In 2009 we see a reversal of this pattern: then, $25 \%$ of all the negative words come from articles mentioning bonuses, and only $22 \%$ come from articles mentioning options. Hence, the time series of press coverage shown in Figure 2 indicate that options have been more in the public eye and generated more negative coverage than any other type of pay until 2008.

A natural question is why the public suddenly focuses on a particular aspect of CEO pay. The public focus on options in the earlier years in the sample may be due to the dramatic increase in options pay after 1994. Three factors may have lead to this increase. First, the regulation passed in 1993 limiting the corporate tax deduction of non-performance-based executive compensation to $\$ 1$ million per year made options more attractive than, for instance, salary (Rose and Wolfram 2002). Second, accounting rules did not require firms to expense option grants until 2005, thus making options a cheaper form of compensation than other types of pay, such as restricted stock. Third, high stock market returns during that period increased the value of option grants. The public concern regarding options may have further escalated because of a series of corporate scandals (e.g., Enron), some of which were related to option backdating practices. As a consequence, new accounting rules were passed in 2004 that required firms to subtract the value of option grants from corporate earnings after 2005, thus reducing the attractiveness of options-based pay and perhaps leading to the decrease (shown in Figure 2) in the negativity of press coverage of this type of compensation in the later part of the sample. Finally, the switch in the public's focus to bonuses post-2008 might have been triggered by AIG's decision to award large bonuses to its executives in spite of using taxpayer money from the bailout fund (Welsh 2009).

\subsection{Impact of Negativity on CEO Pay}

We start our analysis by using annual pay data from Execucomp to investigate whether negativity in the press regarding CEO pay in a particular year predicts CEO compensation in the following year. We examine total CEO compensation, as well as the value of each pay component: salary, bonus, options, stocks, and the residual category, i.e., other pay, as well as the excess value of pay defined as in Core et al. (2008). ${ }^{6}$ In the main analysis we use the natural logarithm of pay, $\ln \left(1+\right.$ Pay $\left._{i, t}\right)$, to minimize the effect of outliers in the pay distribution.

When predicting compensation of firm $i$ 's CEO in year $t$, we include controls for firm-specific and marketwide variables measured as of time $t-1$ that may influence CEO pay. Core et al. (2008) show that

${ }^{6}$ We follow Core et al. (2008) and compute excess pay and log of excess pay for the CEO of firm $i$ in year $t$ as the actual compensation minus expected compensation. The variable $\operatorname{Ln}\left(\right.$ ExcessPay $\left._{i, t}\right)$ is equal to the difference between $\operatorname{Ln}\left(\operatorname{Pay}_{i, t}\right)$ and the predicted value from the regression of $\operatorname{Ln}\left(\right.$ Pay $\left._{i, t}\right)$ on $\operatorname{Ln}\left(\right.$ Sales $\left._{i, t-1}\right), S \& P 500_{t-1}$, Book-to-market $_{i, t-1}$, StockRet ${ }_{i, t}$, StockRet ${ }_{i, t-1}, R O A_{i, t}, R_{i, t-1}, C E O$ $A g e_{i, t}$, and industry fixed effects; ExcessPay ${ }_{i, t}$ is equal to the difference between dollar value of pay and its predicted value from the regression of $\mathrm{Pay}_{i, t}$ on Sales $_{i, t-1}, \mathrm{~S} \& \mathrm{P} 00_{t-1}$, Book-to-market $_{i, t-1}$, StockRet $_{i, t}$, StockRet $_{i, t-1}$, ROA $_{i, t}$, ROA $_{i, t-1}$, CEO Age $e_{i, t}$, and industry fixed effects. 
there is a strong relationship between current and lagged CEO pay. Therefore, the lagged value of the specific pay component that serves as the left-handside variable, $\ln \left(1+\right.$ Pay $\left._{i, t-1}\right)$, is included. We also include measures of lagged firm performance (stock return, return on assets, and sales growth in year $t-1$ ) because better-performing managers will be better remunerated. We control for lagged firm sales, which has been used as a measure for firm size and complexity (e.g., Baker et al. 1988), and for the lagged market value, which is a proxy for the present value of the firm's growth opportunities, because these firm characteristics have been shown to influence CEO pay (e.g., Murphy 1999). ${ }^{7}$ We further include the Bebchuk et al. (2009) entrenchment index because powerful CEOs may extract more pay, because well as the firm's stock volatility because it can mechanically drive the value of compensation, particularly the value of option grants. ${ }^{8}$ We control for the lagged return of the S\&P 500 index to capture the impact of changes in aggregate market conditions on CEO pay and include an indicator variable equal to one if the CEO of the firm is younger than 60 years to control for age-dependent heterogeneity in the executives' outside options and career concerns (Gibbons and Murphy 1992). Finally, a year trend variable is included to account for the possibility that overall CEO pay or its individual components increase over time. ${ }^{9}$

In panel $\mathrm{A}$ of Table 3 we present the results of a pooled ordinary least squares (OLS) model with fixed effects for the Fama and French (1997) 48 industry codes and for the state where the firms' headquarters are located to account for sector and geographic differences in compensation. Although press negativity does not significantly change the log value of total or excess compensation (consistent with the finding of Core et al. 2008), it has a significant effect on the composition of CEO pay. In particular, higher negativity in the prior year leads to a decrease in the log value of option grants and an increase in the log value of salary, bonus, stock awards, and other pay.

To make the magnitude of the log-based results easier to grasp, we compute the effect of changes in press negativity on the percentage change in the

\footnotetext{
${ }^{7}$ Using Tobin's $Q$ as a control instead of the market value of equity does not change the results.

${ }^{8}$ The Bebchuk et al. (2009) entrenchment index is based on six measures that indicate how protected the top management is from shareholder actions or takeover attempts (e.g., whether there exist executive golden parachutes or poison pills.) Higher values of the index indicate weaker governance. We also repeated our analysis using the Gompers et al. (2003) corporate governance index and found similar results.

${ }^{9}$ Our results are robust to the inclusion of a quadratic time trend to account for exponential growth in CEO pay.
}

dollar value of each pay component: ${ }^{10}$ An increase of one standard deviation (see Table 2 for summary statistics) in the negativity of national press coverage toward CEO compensation is followed by a decrease of $8 \%$ in the value of options compensation and an increase of $5 \%$ in salary and bonus, $8 \%$ in stock awards, and $4 \%$ in other compensation. All of the effects reported here are statistically significant at conventional levels. The standard errors are corrected for heteroskedasticity and clustered by firm.

The coefficients on our control variables have the expected sign. CEOs get paid more after better firm performance measured by stock returns, ROA, and sales growth if the company has increased sales or market value or if the prior year's stock market return is higher. They also get paid more in firms with weaker corporate governance as measured by the Bebchuk et al. (2009) index. In addition, we observe that CEOs younger than 60 years get significantly more options and stock-based compensation and lower other compensation compared to CEOs above that age threshold. Also, consistent with earlier research (Murphy 1999, Bebchuk and Fried 2004), we find a strong positive time trend in total compensation, as well as excess compensation.

In panel B of Table 3 we estimate the model including firm fixed effects. Note that in this specification we can not include lagged pay as a control variable because within-group fixed effects estimators are biased and inconsistent in the presence of lagged dependent variables. We obtain similar results as in panel $\mathrm{A}$, that is, firms respond to public negativity toward CEO pay by substituting away from options toward other forms of pay. In the firm fixed effects specification, we also find a significantly negative impact of press negativity on total and excess compensation.

\subsection{Identification Strategies}

Although the results in Table 3 demonstrate a link between press negativity and CEO pay, they do not allow us to make any causal statements. It is possible that public outrage about CEO pay not only changes future $\mathrm{CEO}$ compensation but is also a result of excessive CEO pay in prior years. We develop two different identification strategies to address causality concerns. The first strategy is based on an econometric approach whereby we estimate a system GMM model that accounts for dynamic endogeneity of pay and public opinion. The second strategy is based on a different data set that allows us to use exogenous variation in a firm's fiscal year end to establish causality.

\footnotetext{
${ }^{10}$ That is, we report the value of $\Delta$ Pay $/$ Pay $=e^{\left(\Delta \text { Negativity } * \beta_{\text {Negativity }}\right)}-1$, where $\Delta$ Negativity refers to a one-standard-deviation change in NationalNegativity, and $\beta_{\text {Negativity }}$ is the coefficient estimated in Table 3.
} 
CEO Compensation and National Attitudes: OLS and Firm Fixed Effects

\begin{tabular}{|c|c|c|c|c|c|c|}
\hline & $\begin{array}{c}\text { Total } \\
\text { Comp }_{i, t}\end{array}$ & Options $_{i, t}$ & $\begin{array}{l}\text { Salary+ } \\
\text { Bonus }_{i, t}\end{array}$ & $\begin{array}{l}\text { Other } \\
\text { Pay }_{i, t}\end{array}$ & Stock $_{i, t}$ & $\begin{array}{l}\text { Excess } \\
\text { Pay }_{i, t}\end{array}$ \\
\hline \multicolumn{7}{|c|}{ Panel A: Pooled OLS } \\
\hline Negativity_National $_{t-1}$ & $\begin{array}{l}-0.05 \\
(-1.18)\end{array}$ & $\begin{array}{l}-0.74 \\
(-4.57)^{* * *}\end{array}$ & $\begin{array}{c}0.41 \\
(11.57)^{* * *}\end{array}$ & $\begin{array}{c}0.39 \\
(4.95)^{* * *}\end{array}$ & $\begin{array}{l}0.74 \\
(5.05)^{* * *}\end{array}$ & $\begin{array}{l}-0.01 \\
(-0.14)\end{array}$ \\
\hline Pay $_{i, t-1}$ & $\begin{array}{c}0.53 \\
(19.85)^{* * *}\end{array}$ & $\begin{array}{c}0.41 \\
(37.19)^{* * *}\end{array}$ & $\begin{array}{c}0.73 \\
(34.06)^{* * *}\end{array}$ & $\begin{array}{c}0.65 \\
(68.60)^{* * *}\end{array}$ & $\begin{array}{c}0.50 \\
(48.49)^{* * *}\end{array}$ & $\begin{array}{c}0.56 \\
(19.99)^{* * *}\end{array}$ \\
\hline StockRet $_{t-1}$ & $\begin{array}{l}0.07 \\
(4.28)^{* * *}\end{array}$ & $\begin{array}{c}0.07 \\
(1.48)\end{array}$ & $\begin{array}{c}-0.01 \\
(-1.13)\end{array}$ & $\begin{array}{l}0.04 \\
(2.19)^{* *}\end{array}$ & $\begin{array}{l}-0.12 \\
(-3.34)^{* * *}\end{array}$ & $\begin{array}{l}-0.11 \\
(-6.19)^{* * *}\end{array}$ \\
\hline$R O A_{t-1}$ & $\begin{array}{l}-0.18 \\
(-2.17)^{* *}\end{array}$ & $\begin{array}{l}-0.57 \\
(-2.08)^{* *}\end{array}$ & $\begin{array}{l}-0.39 \\
(-6.13)^{* * *}\end{array}$ & $\begin{array}{l}-0.12 \\
(-0.91)\end{array}$ & $\begin{array}{l}-0.45 \\
(-2.03)^{* *}\end{array}$ & $\begin{array}{c}-0.09 \\
(-0.92)\end{array}$ \\
\hline SalesGrowth $_{t-1}$ & $\begin{array}{c}0.36 \\
(12.87)^{* * *}\end{array}$ & $\begin{array}{c}0.19 \\
(1.92)^{*}\end{array}$ & $\begin{array}{c}0.30 \\
(13.77)^{* * *}\end{array}$ & $\begin{array}{l}0.24 \\
(5.51)^{* * *}\end{array}$ & $\begin{array}{l}0.45 \\
(5.54)^{* * *}\end{array}$ & $\begin{array}{l}0.27 \\
(8.84)^{* * *}\end{array}$ \\
\hline Sales $_{t-1}$ & $\begin{array}{c}0.13 \\
(12.77)^{* * *}\end{array}$ & $\begin{array}{c}0.05 \\
(1.53)\end{array}$ & $\begin{array}{l}0.07 \\
(8.69)^{* * *}\end{array}$ & $\begin{array}{c}0.20 \\
(12.91)^{* * *}\end{array}$ & $\begin{array}{c}0.31 \\
(10.80)^{* * *}\end{array}$ & $\begin{array}{l}-0.05 \\
(-4.62)^{* * *}\end{array}$ \\
\hline MarketValue $_{t-1}$ & $\begin{array}{l}0.11 \\
(7.81)^{* * *}\end{array}$ & $\begin{array}{c}0.44 \\
(12.27)^{* * *}\end{array}$ & $\begin{array}{l}-0.00 \\
(-0.02)\end{array}$ & $\begin{array}{l}-0.00 \\
(-0.11)\end{array}$ & $\begin{array}{c}0.02 \\
(0.80)\end{array}$ & $\begin{array}{l}0.08 \\
(5.98)^{* * *}\end{array}$ \\
\hline Volatility $_{t-1}$ & $\begin{array}{l}0.19 \\
(4.01)^{* * *}\end{array}$ & $\begin{array}{c}0.71 \\
(5.29)^{* * *}\end{array}$ & $\begin{array}{c}0.05 \\
(1.53)\end{array}$ & $\begin{array}{l}-0.20 \\
(-3.37)^{* * *}\end{array}$ & $\begin{array}{l}-0.13 \\
(-0.92)\end{array}$ & $\begin{array}{l}0.19 \\
(4.46)^{* * *}\end{array}$ \\
\hline Eindex $_{t-1}$ & $\begin{array}{l}0.03 \\
(5.62)^{* * *}\end{array}$ & $\begin{array}{l}0.14 \\
(7.22)^{* * *}\end{array}$ & $\begin{array}{l}0.01 \\
(2.12)^{* *}\end{array}$ & $\begin{array}{l}0.06 \\
(6.46)^{* * *}\end{array}$ & $\begin{array}{l}0.15 \\
(8.22)^{* * *}\end{array}$ & $\begin{array}{l}0.04 \\
(7.02)^{* * *}\end{array}$ \\
\hline$S P 500 R E T_{t-1}$ & $\begin{array}{l}0.18 \\
(5.91)^{* * *}\end{array}$ & $\begin{array}{c}0.20 \\
(1.66)^{*}\end{array}$ & $\begin{array}{c}0.02 \\
(0.67)\end{array}$ & $\begin{array}{c}0.00 \\
(0.03)\end{array}$ & $\begin{array}{c}0.36 \\
(3.23)^{* * *}\end{array}$ & $\begin{array}{c}0.35 \\
(11.22)^{* * *}\end{array}$ \\
\hline CEOIsUnder60 ${ }_{t}$ & $\begin{array}{l}0.04 \\
(3.24)^{* * *}\end{array}$ & $\begin{array}{l}0.48 \\
(9.66)^{* * *}\end{array}$ & $\begin{array}{c}-0.01 \\
(-1.35)\end{array}$ & $\begin{array}{l}-0.10 \\
(-4.40)^{* * *}\end{array}$ & $\begin{array}{l}0.22 \\
(4.96)^{* * *}\end{array}$ & $\begin{array}{c}0.00 \\
(0.20)\end{array}$ \\
\hline Year $_{t}$ & $\begin{array}{l}0.01 \\
(6.87)^{* * *}\end{array}$ & $\begin{array}{c}-0.06 \\
(-10.62)^{* * *}\end{array}$ & $\begin{array}{c}-0.01 \\
(-14.62)^{* * *}\end{array}$ & $\begin{array}{c}0.00 \\
(0.13)\end{array}$ & $\begin{array}{c}0.11 \\
(19.53)^{* * *}\end{array}$ & $\begin{array}{l}0.01 \\
(5.26)^{* * *}\end{array}$ \\
\hline Adjusted $R^{2}$ & 0.60 & 0.30 & 0.64 & 0.61 & 0.40 & 0.38 \\
\hline Observations & 19,658 & 19,668 & 19,923 & 19,709 & 19,908 & 16,371 \\
\hline \multicolumn{7}{|c|}{ Panel B: Firm fixed effects } \\
\hline Negativity_National ${ }_{t-1}$ & $\begin{array}{l}-0.19 \\
(-4.03)^{* * *}\end{array}$ & $\begin{array}{l}-0.97 \\
(-5.31)^{* * *}\end{array}$ & $\begin{array}{c}0.50 \\
(11.29)^{* * *}\end{array}$ & $\begin{array}{l}0.32 \\
(3.52)^{* * *}\end{array}$ & $\begin{array}{l}0.56 \\
(3.29)^{* * *}\end{array}$ & $\begin{array}{l}-0.24 \\
(-5.20)^{* * *}\end{array}$ \\
\hline Adjusted $R^{2}$ & 0.66 & 0.35 & 0.58 & 0.62 & 0.44 & 0.46 \\
\hline Observations & 19,933 & 19,937 & 20,031 & 19,953 & 20,024 & 19,749 \\
\hline
\end{tabular}

Notes. This table presents the estimated effects of the negativity of national press coverage on CEO pay. Executive compensation is measured in log values. Fama-French 48 industry code fixed effects and firm headquarters state fixed effects are included in the first specification (pooled OLS) in panel A. The second specification (panel B) includes firm fixed effects. Standard errors are corrected for heteroskedasticity and clustered at the firm level. All variables are described in Table 1.

${ }^{*} p<0.10 ;{ }^{* *} p<0.05 ;{ }^{* * *} p<0.01$.

In Table 4 we estimate a system GMM model designed specifically to account for dynamic endogeneity in panel data (Blundell and Bond 1998). The estimation is done in two steps. First, we specify the model in first difference form to eliminate any firmlevel unobserved heterogeneity:

$$
\begin{aligned}
\operatorname{CEOComp~}_{i, t}= & \alpha+\kappa_{p} \sum_{p} \Delta \text { CEOComp }_{i, t-p} \\
& +\beta_{1} \cdot \Delta \text { Negativity }_{t-1} \\
& +\delta \cdot \Delta X_{i, t}+\gamma \cdot \Delta Z_{i, t}+\Delta \epsilon_{i, t} .
\end{aligned}
$$

We are primarily interested in the effect of coefficient $\beta_{1}$. The symbol $X_{i, t}$ denotes the set of control variables (the same as in Table 3), and $Z_{i, t}$ denotes the set of instruments. The idea of system GMM is to model dynamic endogeneity by using lagged explanatory variables as instruments for current explanatory variables. In our case, we use lagged values of CEO compensation, negativity, and other firmspecific variables as instruments for current changes in these variables. Dynamic completeness of the equation is ensured by including all significant lags $p$ of the dependent variable into the equation. ${ }^{11}$ The number of lags included for each dependent variable in

${ }^{11}$ This yields the following orthogonality conditions: $E\left(X_{i, t-s} \epsilon_{i, t}\right)=$ $E\left(Z_{i, t-s} \epsilon_{i, t}\right)=E\left(y_{i, t-s} \epsilon_{i, t}\right)=0 ; \forall s>p$. 
Table 4

CEO Compensation and National Attitudes: GMM Results

\begin{tabular}{|c|c|c|c|c|c|c|}
\hline & $\begin{array}{c}\text { Total } \\
\text { Comp } \\
\text { i,t }\end{array}$ & Options $_{i, t}$ & $\begin{array}{l}\text { Salary+ } \\
\text { Bonus }_{i, t}\end{array}$ & $\begin{array}{l}\text { Other } \\
\text { Pay }_{i, t}\end{array}$ & Stock $_{i, t}$ & $\begin{array}{l}\text { Excess } \\
\text { Pay }_{i, t}\end{array}$ \\
\hline Negativity_National $_{t-1}$ & $\begin{array}{l}-0.29 \\
(-1.05)\end{array}$ & $\begin{array}{c}-1.17 \\
(-1.91)^{*}\end{array}$ & $\begin{array}{l}2.43 \\
(5.60)^{* * *}\end{array}$ & $\begin{array}{l}1.32 \\
(4.04)^{* * *}\end{array}$ & $\begin{array}{l}1.25 \\
(2.76)^{* * *}\end{array}$ & $\begin{array}{c}-0.19 \\
(-0.44)\end{array}$ \\
\hline StockRet $_{i, t-1}$ & $\begin{array}{c}0.34 \\
(1.58)\end{array}$ & $\begin{array}{c}0.44 \\
(0.61)\end{array}$ & $\begin{array}{c}0.60 \\
(1.08)\end{array}$ & $\begin{array}{c}0.42 \\
(1.54)\end{array}$ & $\begin{array}{l}-0.71 \\
(-2.45)^{* *}\end{array}$ & $\begin{array}{l}-0.20 \\
(-0.52)\end{array}$ \\
\hline$R O A_{i, t-1}$ & $\begin{array}{c}1.49 \\
(1.00)\end{array}$ & $\begin{array}{c}3.92 \\
(0.73)\end{array}$ & $\begin{array}{c}3.79 \\
(1.46)\end{array}$ & $\begin{array}{c}1.06 \\
(0.46)\end{array}$ & $\begin{array}{c}1.66 \\
(0.88)\end{array}$ & $\begin{array}{l}-0.89 \\
(-0.53)\end{array}$ \\
\hline SalesGrowth $_{i, t-1}$ & $\begin{array}{l}1.10 \\
(2.69)^{* * *}\end{array}$ & $\begin{array}{c}0.49 \\
(0.42)\end{array}$ & $\begin{array}{l}-4.63 \\
(-2.15)^{* *}\end{array}$ & $\begin{array}{c}-0.39 \\
(-0.54)\end{array}$ & $\begin{array}{c}0.11 \\
(0.14)\end{array}$ & $\begin{array}{c}0.13 \\
(0.17)\end{array}$ \\
\hline $\operatorname{Ln}\left(\right.$ Sales $\left._{i, t-1}\right)$ & $\begin{array}{c}0.04 \\
(0.20)\end{array}$ & $\begin{array}{l}-1.93 \\
(-2.57)^{* * *}\end{array}$ & $\begin{array}{l}-0.16 \\
(-0.39)\end{array}$ & $\begin{array}{l}1.21 \\
(3.53)^{* * *}\end{array}$ & $\begin{array}{c}0.14 \\
(0.52)\end{array}$ & $\begin{array}{c}0.08 \\
(0.32)\end{array}$ \\
\hline $\operatorname{Ln}_{\left(\text {MarketValue }_{i, t-1}\right)}$ & $\begin{array}{c}0.07 \\
(0.30)\end{array}$ & $\begin{array}{l}1.88 \\
(3.02)^{* * *}\end{array}$ & $\begin{array}{c}0.20 \\
(0.53)\end{array}$ & $\begin{array}{l}-0.76 \\
(-2.98)^{* * *}\end{array}$ & $\begin{array}{c}-0.15 \\
(-0.62)\end{array}$ & $\begin{array}{l}-0.04 \\
(-0.22)\end{array}$ \\
\hline Volatility $_{i, t-1}$ & $\begin{array}{c}0.27 \\
(0.82)\end{array}$ & $\begin{array}{c}1.26 \\
(1.14)\end{array}$ & $\begin{array}{c}1.00 \\
(1.06)\end{array}$ & $\begin{array}{c}0.03 \\
(0.08)\end{array}$ & $\begin{array}{l}-0.99 \\
(-1.51)\end{array}$ & $\begin{array}{c}0.56 \\
(0.75)\end{array}$ \\
\hline Eindex $_{i, t-1}$ & $\begin{array}{c}0.06 \\
(0.57)\end{array}$ & $\begin{array}{c}0.53 \\
(1.48)\end{array}$ & $\begin{array}{c}0.09 \\
(0.51)\end{array}$ & $\begin{array}{c}-0.09 \\
(-0.98)\end{array}$ & $\begin{array}{c}0.15 \\
(1.24)\end{array}$ & $\begin{array}{l}-0.03 \\
(-0.28)\end{array}$ \\
\hline$S P 500 R E T_{t-1}$ & $\begin{array}{c}-0.06 \\
(-0.33)\end{array}$ & $\begin{array}{l}-0.80 \\
(-1.08)\end{array}$ & $\begin{array}{c}0.08 \\
(0.11)\end{array}$ & $\begin{array}{l}-0.17 \\
(-0.49)\end{array}$ & $\begin{array}{l}0.97 \\
(3.06)^{* * *}\end{array}$ & $\begin{array}{c}0.43 \\
(1.14)\end{array}$ \\
\hline CEOIsUnder $60_{i, t}$ & $\begin{array}{c}0.05 \\
(2.28)^{* *}\end{array}$ & $\begin{array}{c}0.58 \\
(5.00)^{* * *}\end{array}$ & $\begin{array}{l}-0.02 \\
(-0.44)\end{array}$ & $\begin{array}{l}-0.13 \\
(-2.71)^{* * *}\end{array}$ & $\begin{array}{l}0.44 \\
(5.44)^{* * *}\end{array}$ & $\begin{array}{l}-0.01 \\
(-0.19)\end{array}$ \\
\hline Year $_{t}$ & $\begin{array}{c}0.01 \\
(0.85)\end{array}$ & $\begin{array}{l}-0.26 \\
(-5.18)^{* * *}\end{array}$ & $\begin{array}{l}-0.06 \\
(-3.53)^{* * *}\end{array}$ & $\begin{array}{l}-0.01 \\
(-0.90)\end{array}$ & $\begin{array}{l}0.19 \\
(6.63)^{* * *}\end{array}$ & $\begin{array}{c}0.03 \\
(1.36)\end{array}$ \\
\hline $\operatorname{Ln}\left(P a y_{i, t-1}\right)$ & $\begin{array}{c}0.21 \\
(0.84)\end{array}$ & $\begin{array}{c}-0.14 \\
(-0.83)\end{array}$ & $\begin{array}{c}0.68 \\
(1.36)\end{array}$ & $\begin{array}{l}0.43 \\
(3.02)^{* * *}\end{array}$ & $\begin{array}{l}0.32 \\
(9.05)^{* * *}\end{array}$ & $\begin{array}{c}0.54 \\
(1.56)\end{array}$ \\
\hline $\operatorname{Ln}\left(P a y_{i, t-2}\right)$ & $\begin{array}{c}0.07 \\
(0.33)\end{array}$ & $\begin{array}{l}-0.12 \\
(-0.89)\end{array}$ & $\begin{array}{l}-0.49 \\
(-1.02)\end{array}$ & $\begin{array}{l}0.38 \\
(2.43)^{* * *}\end{array}$ & $\begin{array}{l}0.10 \\
(2.74)^{* * *}\end{array}$ & $\begin{array}{c}-0.24 \\
(-0.75)\end{array}$ \\
\hline $\operatorname{Ln}\left(P a y_{i, t-3}\right)$ & $\begin{array}{c}0.09 \\
(0.57)\end{array}$ & $\begin{array}{l}0.27 \\
(2.25)^{* *}\end{array}$ & & $\begin{array}{c}0.16 \\
(0.74)\end{array}$ & $\begin{array}{c}-0.02 \\
(-0.43)\end{array}$ & $\begin{array}{l}-0.04 \\
(-0.11)\end{array}$ \\
\hline $\operatorname{Ln}\left(P a y_{i, t-4}\right)$ & $\begin{array}{c}0.06 \\
(1.77)\end{array}$ & $\begin{array}{l}0.06 \\
(1.65)^{*}\end{array}$ & & $\begin{array}{l}-0.08 \\
(-0.87)\end{array}$ & $\begin{array}{l}-0.16 \\
(-1.94)^{*}\end{array}$ & $\begin{array}{l}-0.01 \\
(-0.04)\end{array}$ \\
\hline $\operatorname{Ln}\left(P_{a y}{ }_{i, t-5}\right)$ & & $\begin{array}{c}0.01 \\
(0.37)\end{array}$ & & $\begin{array}{c}-0.04 \\
(-1.24)\end{array}$ & $\begin{array}{c}0.44 \\
(1.94)^{*}\end{array}$ & \\
\hline Observations & 12,801 & 10,921 & 17,583 & 10,926 & 11,300 & 8,844 \\
\hline $\mathrm{AR}(1)$ test ( $p$-value) & $(0.03)$ & $(0.04)$ & $(0.00)$ & $(0.02)$ & $(0.00)$ & $(0.05)$ \\
\hline AR(2) test ( $p$-value) & $(0.96)$ & $(0.57)$ & $(0.15)$ & $(0.40)$ & $(0.73)$ & $(0.47)$ \\
\hline Hansen test of overidentification ( $p$-value) & $(0.45)$ & $(0.54)$ & $(0.87)$ & $(0.53)$ & $(0.34)$ & $(0.89)$ \\
\hline Diff.-in-Hansen test of exogeneity ( $p$-value) & $(0.76)$ & $(0.38)$ & $(0.68)$ & $(0.65)$ & $(0.21)$ & $(0.50)$ \\
\hline
\end{tabular}

Notes. This table presents the estimated effects of the negativity of national press coverage on CEO pay. CEO pay is measured in log values. The results are based on a system GMM model (Arellano and Bond 1991, Blundell and Bond 1998) estimated as in Equation (2). Standard errors are corrected for heteroskedasticity and clustered at the firm level. All variables are described in Table 1. AR(1) and $A R(2)$ are tests for first-order and secondorder serial correlation in the first-differenced residuals, under the null of no serial correlation. The Hansen test of overidentification is under the null that all instruments are valid. The difference-in-Hansen test of exogeneity is under the null that instruments used for the equations in levels are exogenous.

${ }^{*} p<0.10 ;{ }^{* *} p<0.05 ;{ }^{* * *} p<0.01$.

Table 4 differs according to how many lags are statistically significant in the corresponding regression.

We then estimate the level and difference equations simultaneously: ${ }^{12}$

\footnotetext{
${ }^{12}$ Note, that the level equations still include unobserved heterogeneity, $\eta_{i}$. We follow Wintoki et al. (2012) and assume that the correlation between negativity and control variables is constant over time. This assumption leads to another set of orthogonality conditions: $E\left[\Delta X_{i, t-s}\left(\eta_{i}+\epsilon_{i, t}\right)\right]=E\left[\Delta Z_{i, t-s}\left(\eta_{i}+\epsilon_{i, t}\right)\right]=E\left[\Delta y_{i, t-s}\left(\eta_{i}+\epsilon_{i, t}\right)\right]=0$, $\forall s>p$.
}

$$
\begin{aligned}
& {\left[\begin{array}{l}
\text { CEOComp }_{i, t} \\
\Delta \text { CEOComp }_{i, t}
\end{array}\right]} \\
& =\alpha+\kappa\left[\begin{array}{c}
\sum_{p} \text { CEOComp }_{i, t-p} \\
\sum_{p} \Delta \text { CEOComp }_{i, t-p}
\end{array}\right]+\beta_{1}\left[\begin{array}{l}
\text { Negativity }_{t-1} \\
\Delta \text { Negativity }_{t-1}
\end{array}\right] \\
& +\delta\left[\begin{array}{c}
X_{i, t} \\
\Delta X_{i, t}
\end{array}\right]+\gamma\left[\begin{array}{c}
Z_{i, t} \\
\Delta Z_{i, t}
\end{array}\right]+\epsilon_{i, t} .
\end{aligned}
$$


Variables CEOComp $p_{i, t}$ and $\triangle C E O C o m p_{i, t}$ denote the level and year to year change (from $t-1$ to $t$ ) in total pay or individual pay components (e.g., options) for firm $i$. The level and change in mean press negativity are captured by Negativity $t_{t-1}$ and $\Delta$ Negativity $_{t-1}$. The validity of instruments $Z_{i, t}$ is analyzed with serial correlation tests and the Hansen test of overidentification (Arellano and Bond 1991) and shown by the test statistics in Table $3 .{ }^{13}$ Serial correlation tests show that the assumptions of our specifications are valid: the residuals in first differences $(A R(1))$ are significantly correlated, but there is no serial correlation in second differences $(A R(2))$. Furthermore, the Hansen test reveals insignificant $p$-values in all specifications, meaning the null hypothesis that our instruments are valid can not be rejected. Finally, the difference-inHansen test reveals that the subset of instruments used in the levels equations is also exogenous for all specifications. As shown in Table 4, the system GMM results also indicate that high negativity of media coverage regarding CEO compensation leads to significantly lower options-based compensation in the subsequent year, and higher salary and bonuses, stock awards, and other pay.

Overall, the results in Tables 3 and 4 show that the impact of the prior year's negativity on CEO pay in the current year is similar in terms of economic magnitude and statistical significance across the pooled OLS, firm fixed effects, and system GMM specifications, yielding support for a causal influence of public opinion over the firms' decision regarding the composition, but not the level, of executive pay. Nevertheless, it is still possible that in spite of using numerous controls and estimating a dynamic GMM model to address endogeneity concerns, the link between negativity and pay is not in fact causal. For instance, unobservable events in a particular year omitted so far in the analysis can drive both press negativity and subsequent annual pay.

Therefore, our second identification strategy is based on the Thomson Reuters Insiders Filings database, which provides the time and size of all option and stock awards given to CEOs of publicly traded companies during 1996-2008. Here, an observation unit is at the firm-grant level. This allows us to use within-year variation in negativity as well as in the size and timing of these awards. Therefore, by including year, calendar month, and firm fixed effects, we address the concern that certain events-such as changes in accounting rules related to $\mathrm{CEO}$ pay or unknown omitted variables-that occur in some of the years in the sample drive the relationship between negativity and pay. To further test the robustness of

\footnotetext{
${ }^{13}$ See Wintoki et al. (2012) for discussion of estimating system GMM models and relevant STATA commands.
}

our results, we examine whether grants made at times determined exogenously (i.e., two months after the firm's fiscal year end) respond to public negativity in the prior three to six months. The drawback of this analysis is that the Thomson database only contains information on option and stock grants and not on other types of pay.

For our identification strategy to work, there needs to be variation within year and within firm in the dates of grant awards. This is indeed the case, as grants are made in every calendar month: $15 \%$ of option grants in the sample are made in February, $8 \%$ in each of April and May, and 11\% in December, and the rest are spread out relatively evenly among the remaining months. Moreover, although each firm tends to concentrate its grants in a particular calendar month (typically two months after the end of the fiscal year), $46 \%$ of the firms' grants are made during other calendar months.

We estimate the impact of press negativity on options and stock pay using regression models that include firm fixed effects, year fixed effects, calendar month fixed effects, as well as time-variant firm controls such as performance and size. Calendar month fixed effects allow us to control for within-year seasonality in press coverage and CEO pay. To exploit withinyear variation in negativity, we use either the three or six months prior to the grant date as the window during which we measure average negativity in national newspaper articles about CEO pay. We use log as well as dollar values of option grants. As shown in panel A of Table 5, option grants decrease in value if press negativity is higher in the recent months before the grant date, suggesting that firms respond to withinyear variation in public opinion when choosing the structure of CEO compensation. An increase of one standard deviation in the prior three-month negativity corresponds to a decrease of $4 \%$, or $\$ 36,182$, in the value of individual option grants awarded.

Importantly, as in the annual data, we find that negativity does not influence all pay components in the same direction. As can be seen in the regressions in panel B of Table 5, increasing the prior threemonth negativity by one standard deviation leads to an increase of $5 \%$, or $\$ 13,482$, in the value of individual stock grants awarded to CEOs. The effect of negativity on stock grants is consistently positive, whether we use the prior three- or prior six-month negativity, or whether we use log or dollar values for these grants. The effects on grant composition are in fact stronger if we measure average negativity over the prior six months instead of the prior three months: if the prior six-month negativity increases by one standard deviation, the value of options grants falls by $6 \%$, and the value of stock grants increases by $9 \%$. This result indicates that if the public outrage is 
Table 5 Option and Stock Grants, Monthly Data

\begin{tabular}{|c|c|c|c|c|}
\hline Panel A & $\operatorname{Ln}\left(\right.$ Options $\left._{i, m}\right)$ & $\operatorname{Ln}\left(\right.$ Options $\left._{i, m}\right)$ & \$Options $_{i, m}$ & \$Options $_{i, m}$ \\
\hline NationalNegativity $_{[m-3, m-1]}$ & $\begin{array}{l}-0.24 \\
(-1.84)^{*}\end{array}$ & & $\begin{array}{r}-241,213.38 \\
(-2.35)^{* *}\end{array}$ & \\
\hline NationalNegativity $_{[m-6, m-1]}$ & & $\begin{array}{l}-0.46 \\
(-2.44)^{* *}\end{array}$ & & $\begin{array}{r}-367,918.84 \\
(-2.15)^{* *}\end{array}$ \\
\hline StockRet $_{i, t-1}$ & $\begin{array}{l}0.00 \\
(0.74)\end{array}$ & $\begin{array}{c}0.00 \\
(0.69)\end{array}$ & $\begin{array}{l}-13.84 \\
(-0.78)\end{array}$ & $\begin{array}{l}-14.08 \\
(-0.79)\end{array}$ \\
\hline$R O A_{i, t-1}$ & $\begin{array}{l}-0.00 \\
(-0.29)\end{array}$ & $\begin{array}{l}-0.00 \\
(-0.25)\end{array}$ & $\begin{array}{r}257.98 \\
(1.06)\end{array}$ & $\begin{array}{r}283.31 \\
(1.13)\end{array}$ \\
\hline SalesGrowth $_{i, t-1}$ & $\begin{array}{c}0.001 \\
(1.71)^{*}\end{array}$ & $\begin{array}{c}0.001 \\
(1.68)^{*}\end{array}$ & $\begin{array}{l}509.29 \\
(2.99)^{* * *}\end{array}$ & $\begin{array}{l}500.88 \\
(2.92)^{\text {**** }}\end{array}$ \\
\hline $\operatorname{Ln}\left(\right.$ MarketValue $\left._{i, t-1}\right)$ & $\begin{array}{c}0.37 \\
(11.64)^{* * *}\end{array}$ & $\begin{array}{c}0.37 \\
(11.72)^{* * *}\end{array}$ & & \\
\hline MarketValue $_{i, t-1}$ & & & $\begin{array}{l}10.70 \\
(3.20)^{* * *}\end{array}$ & $\begin{array}{l}10.66 \\
(3.19)^{* * *}\end{array}$ \\
\hline Firm fixed effects & YES & YES & YES & YES \\
\hline Calendar month fixed effects & YES & YES & YES & YES \\
\hline Year fixed effects & YES & YES & YES & YES \\
\hline$R^{2}$ & 0.65 & 0.65 & 0.29 & 0.29 \\
\hline Observations & 92,536 & 92,536 & 92,536 & 92,536 \\
\hline Panel B & $\operatorname{Ln}\left(\right.$ Stock $\left._{i, m}\right)$ & $\operatorname{Ln}\left(\right.$ Stock $\left._{i, m}\right)$ & Stock $_{i, m}$ & Stock $_{i, m}$ \\
\hline NationalNegativity $_{[m-3, m-1]}$ & $\begin{array}{l}0.33 \\
(2.18)^{* *}\end{array}$ & & $\begin{array}{r}103,711.28 \\
(2.49)^{* *}\end{array}$ & \\
\hline NationalNegativity $_{[m-6, m-1]}$ & & $\begin{array}{l}0.64 \\
(2.91)^{* * *}\end{array}$ & & $\begin{array}{r}172,132.66 \\
(2.69)^{* * * *}\end{array}$ \\
\hline StockRet $_{i, t-1}$ & $\begin{array}{l}0.0001 \\
(1.77)^{*}\end{array}$ & $\begin{array}{r}0.0001 \\
(1.77)^{*}\end{array}$ & $\begin{array}{l}72.62 \\
(4.73)^{* * *}\end{array}$ & $\begin{array}{l}72.38 \\
(4.76)^{* * *}\end{array}$ \\
\hline$R O A_{i, t-1}$ & $\begin{array}{c}0.00 \\
(0.13)\end{array}$ & $\begin{array}{l}0.00 \\
(0.15)\end{array}$ & $\begin{array}{l}1,973.18 \\
(2.46)^{* *}\end{array}$ & $\begin{array}{l}1,974.23 \\
(2.46)^{* *}\end{array}$ \\
\hline SalesGrowth $_{i, t-1}$ & $\begin{array}{c}0.00 \\
(0.76)\end{array}$ & $\begin{array}{c}0.00 \\
(0.76)\end{array}$ & $\begin{array}{l}-94.01 \\
(-0.43)\end{array}$ & $\begin{array}{l}-93.38 \\
(-0.43)\end{array}$ \\
\hline $\operatorname{Ln}\left(\right.$ MarketValue $\left._{i, t-1}\right)$ & $\begin{array}{l}0.17 \\
(4.03)^{* * *}\end{array}$ & $\begin{array}{l}0.17 \\
(4.00)^{* * *}\end{array}$ & & \\
\hline MarketValue $_{i, t-1}$ & & & $\begin{array}{l}3.03 \\
(2.26)^{* *}\end{array}$ & $\begin{array}{l}3.03 \\
(2.27)^{* *}\end{array}$ \\
\hline Firm fixed effects & YES & YES & YES & YES \\
\hline Calendar month fixed effects & YES & YES & YES & YES \\
\hline Year fixed effects & YES & YES & YES & YES \\
\hline$R^{2}$ & 0.62 & 0.62 & 0.49 & 0.49 \\
\hline Observations & 15,215 & 15,215 & 15,215 & 15,215 \\
\hline
\end{tabular}

Notes. In panel A (B), the dependent variable is either the log or the dollar value of each option (stock) grant made to CEOs of firms covered in Execucomp, as recorded in the Thomson Reuters Insider Filings database during 1996-2008. All regression models include firm fixed effects, year fixed effects, calendar month fixed effects, as well as time-variant firm characteristics (e.g., performance and size). Standard errors are corrected for heteroskedasticity and clustered at the firm-month level. All variables are described in Table 1. ${ }^{*} p<0.10 ;{ }^{* *} p<0.05 ;{ }^{* * *} p<0.01$.

longer lasting, it has a more powerful impact on the firms' executive pay decisions.

To alleviate concerns regarding possible endogeneity in the timing of option and stock grants, we restrict the sample to grants made at times exogenous to public opinion, i.e., times that are fully determined by the firm's fiscal year end. A firm's fiscal year end is set early in its life and is independent of the tone of coverage of CEO pay in the press at a particular point in time. The end of the fiscal year naturally drives the timing of board meetings during the calendar year and therefore the timing of various compensation decisions. As shown by the summary statistics in panel A (panel B) of Table 6, for firms with a specific fiscal year end month (FYEM) the majority of option (stock) grants are given in one particular month, which we will refer to as the "modal" month for the firm. ${ }^{14}$ This typically occurs two months after the FYEM. For example, among firms with an FYEM

${ }^{14}$ Klein and Maug (2009) find that the hazard rate of CEOs exercising options peaks at annual intervals from the vesting date, consistent with our finding that each firm makes these grants around similar times each year. 
The Time of Option and Stock Awards as Function of the Firms' Fiscal Year End Month

\begin{tabular}{|c|c|c|c|c|}
\hline \multicolumn{5}{|c|}{ Panel A } \\
\hline FYEM & $\begin{array}{l}\text { Unique firms } \\
\text { (6-digit CUSIP) }\end{array}$ & $\begin{array}{l}\text { No. of option } \\
\text { grants }\end{array}$ & $\begin{array}{l}\text { Most frequent modal } \\
\text { calendar month for } \\
\text { firms with this FYEM }\end{array}$ & $\begin{array}{c}\text { Percentage of } \\
\text { option grants } \\
\text { made in modal } \\
\text { calendar month }\end{array}$ \\
\hline January & 126 & 4,723 & March & 53.65 \\
\hline February & 41 & 1,253 & April & 51.32 \\
\hline March & 120 & 7,068 & May & 53.18 \\
\hline April & 35 & 1,283 & June & 57.13 \\
\hline May & 44 & 1,579 & July & 49.15 \\
\hline June & 159 & 5,607 & August & 50.65 \\
\hline July & 32 & 1,140 & September & 54.47 \\
\hline August & 46 & 1,624 & October & 64.96 \\
\hline September & 171 & 6,826 & November & 58.38 \\
\hline October & 59 & 2,860 & December & 53.11 \\
\hline November & 25 & 3,344 & December & 45.57 \\
\hline December & 1,506 & 55,229 & February & 54.95 \\
\hline \multicolumn{5}{|c|}{ Panel B } \\
\hline FYEM & $\begin{array}{l}\text { Unique firms } \\
\text { (6-digit CUSIP) }\end{array}$ & $\begin{array}{l}\text { No. of stock } \\
\text { grants }\end{array}$ & $\begin{array}{l}\text { Most frequent modal } \\
\text { calendar month for } \\
\text { firms with this FYEM }\end{array}$ & $\begin{array}{l}\text { Percentage of } \\
\text { stock grants } \\
\text { made in modal } \\
\text { calendar month }\end{array}$ \\
\hline January & 92 & 646 & March & 41.95 \\
\hline February & 30 & 293 & April & 41.64 \\
\hline March & 83 & 708 & May & 34.60 \\
\hline April & 24 & 182 & June & 60.44 \\
\hline May & 30 & 330 & July & 41.52 \\
\hline June & 122 & 994 & August & 47.08 \\
\hline July & 24 & 344 & September & 29.94 \\
\hline August & 37 & 351 & October & 45.58 \\
\hline September & 133 & 938 & November & 49.79 \\
\hline October & 51 & 412 & December & 48.79 \\
\hline November & 15 & 122 & January & 45.90 \\
\hline December & 1,234 & 10,091 & February & 47.78 \\
\hline
\end{tabular}

Notes. For firms with a specific FYEM, panel A (B) of this table shows the majority of option (stock) grants that are given in one particular calendar month, i.e., the "modal" month for the firm, which typically is two months after the FYEM. For example, among firms with an FYEM in December, $54.95 \%$ of option grants are awarded to CEOs in the modal month, and the most frequently occurring modal month across these firms is February. CUSIP, Committee on Uniform Security Identification Procedures.

in December, $54.95 \%$ of option grants are awarded during each firm's modal month, and the most frequently occurring modal month across these firms is February.

We use the subsample of grants made during each firm's modal month to test whether recent press negativity leads firms to avoid option grants when remunerating their CEOs. In panel A of Table 7, we use the same regression models as in Table 5 and find even stronger effects of negativity. Specifically, we find that a one-standard-deviation increase in negativity in the three months before the grant date leads to a $7 \%$ drop in options pay in the sample of exogenously timed grants, whereas in the entire sample used in Table 5 the drop was only $4 \%$. As a robustness check and to be consistent with our previous regressions based on annual data, in panel B we use the same set of firm-year characteristics as in Table 3 (e.g., entrench- ment index, volatility, CEO age), instead of firm fixed effects, and once again find a negative impact of negativity on options pay. Also in line with the evidence documented in Table 5, the results in panel $\mathrm{C}$ of Table 7 show that increased negativity in the three to six months before the grant date is followed by an increase in stock pay in the sample of exogenously timed grants.

\subsection{Robustness Checks}

In additional robustness analyses, we use different measures of press negativity about CEO pay, different measures of compensation (dollar values, as well as excess values computed as in Core et al. 2008), and additional controls to address omitted variable concerns and test the model in different subsamples. The results, based on pooled OLS regressions with industry and state fixed effects are presented in Table 8 and 
Table 7 Option and Stock Grants, Monthly Data, Modal Month Grants Only

\begin{tabular}{|c|c|c|c|c|}
\hline \multicolumn{5}{|c|}{ Panel A } \\
\hline & $\operatorname{Ln}\left(\right.$ Options $\left._{i, m}\right)$ & $\operatorname{Ln}\left(\right.$ Options $\left._{i, m}\right)$ & \$options $_{i, m}$ & SOptions $_{i, m}$ \\
\hline NationalNegativity $_{[m-3, m-1]}$ & $\begin{array}{l}-0.45 \\
(-2.64)^{* * *}\end{array}$ & & $\begin{array}{r}-332,236.38 \\
(-2.22)^{* *}\end{array}$ & \\
\hline NationalNegativity $_{[m-6, m-1]}$ & & $\begin{array}{l}-0.80 \\
(-3.26)^{* * *}\end{array}$ & & $\begin{array}{r}-404,430.08 \\
(-1.64)\end{array}$ \\
\hline StockRet $_{i, t-1}$ & $\begin{array}{l}3 * 10^{-5} \\
(3.29)^{* * *}\end{array}$ & $\begin{array}{l}3 * 10^{-5} \\
(3.26)^{* * *}\end{array}$ & $\begin{array}{l}13.18 \\
(1.39)\end{array}$ & $\begin{array}{l}13.10 \\
(1.40)\end{array}$ \\
\hline$R O A_{i, t-1}$ & $\begin{array}{l}-0.00 \\
(-0.73)\end{array}$ & $\begin{array}{l}-0.00 \\
(-0.67)\end{array}$ & $\begin{array}{r}-368.80 \\
(-0.77)\end{array}$ & $\begin{array}{r}-249.17 \\
(-0.54)\end{array}$ \\
\hline SalesGrowth $_{i, t-1}$ & $\begin{array}{l}0.001 \\
(2.09)^{* *}\end{array}$ & $\begin{array}{c}0.001 \\
(2.04)^{* *}\end{array}$ & $\begin{array}{l}430.70 \\
(1.90)^{*}\end{array}$ & $\begin{array}{l}427.23 \\
(1.90)^{*}\end{array}$ \\
\hline $\operatorname{Ln}\left(\right.$ MarketValue $\left._{i, t-1}\right)$ & $\begin{array}{l}0.36 \\
(7.12)^{* * *}\end{array}$ & $\begin{array}{l}0.36 \\
(7.10)^{* * *}\end{array}$ & & \\
\hline MarketValue $_{i, t-1}$ & & & $\begin{array}{l}10.13 \\
(2.66)^{* * *}\end{array}$ & $\begin{array}{l}10.10 \\
(2.65)^{* * *}\end{array}$ \\
\hline Firm fixed effects & YES & YES & YES & YES \\
\hline Calendar month fixed effects & YES & YES & YES & YES \\
\hline Year fixed effects & YES & YES & YES & YES \\
\hline$R^{2}$ & 0.72 & 0.72 & 0.41 & 0.41 \\
\hline Observations & 50,315 & 50,315 & 50,315 & 50,315 \\
\hline \multicolumn{5}{|c|}{ Panel B } \\
\hline & $\operatorname{Ln}\left(\right.$ Options $\left._{i, m}\right)$ & $\operatorname{Ln}\left(\right.$ Options $\left._{i, m}\right)$ & \$Options $_{i, m}$ & \$Options $_{i, m}$ \\
\hline NationalNegativity $_{[m-3, m-1]}$ & $\begin{array}{l}-0.39 \\
(-1.40)\end{array}$ & & $\begin{array}{l}-463,409.96 \\
(-2.91)^{* * *}\end{array}$ & \\
\hline NationalNegativity $_{[m-6, m-1]}$ & & $\begin{array}{l}-0.72 \\
(-2.09)^{* *}\end{array}$ & & $\begin{array}{r}-656,471.22 \\
(-2.41)^{* *}\end{array}$ \\
\hline StockRet $_{i, t-1}$ & $\begin{array}{c}0.00 \\
(1.33)\end{array}$ & $\begin{array}{l}0.00 \\
(1.34)\end{array}$ & $\begin{array}{l}-1.07 \\
(-0.24)\end{array}$ & $\begin{array}{l}-1.18 \\
(-0.27)\end{array}$ \\
\hline$R O A_{i, t-1}$ & $\begin{array}{c}0.00 \\
(1.30)\end{array}$ & $\begin{array}{c}0.00 \\
(1.34)\end{array}$ & $\begin{array}{l}1,830.66 \\
\quad(4.58)^{* * *}\end{array}$ & $\begin{array}{l}1,894.75 \\
\quad(4.77)^{* * * *}\end{array}$ \\
\hline SalesGrowth $_{i, t-1}$ & $\begin{array}{l}0.00 \\
(0.88)\end{array}$ & $\begin{array}{l}0.00 \\
(0.86)\end{array}$ & $\begin{array}{r}348.15 \\
(1.45)\end{array}$ & $\begin{array}{r}339.67 \\
(1.43)\end{array}$ \\
\hline Volatility $_{i, t-1}$ & $\begin{array}{l}0.01 \\
(0.08)\end{array}$ & $\begin{array}{l}0.01 \\
(0.07)\end{array}$ & $\begin{array}{r}25,790.88 \\
(0.38)\end{array}$ & $\begin{array}{r}23,989.27 \\
(0.35)\end{array}$ \\
\hline Eindex $_{i, t-1}$ & $\begin{array}{l}0.09 \\
(2.36)^{* *}\end{array}$ & $\begin{array}{l}0.09 \\
(2.36)^{* *}\end{array}$ & $\begin{array}{r}15,495.48 \\
(0.96)\end{array}$ & $\begin{array}{r}14,937.69 \\
(0.93)\end{array}$ \\
\hline CEOIsUnder60 $0_{i, t}$ & $\begin{array}{l}0.08 \\
(0.79)\end{array}$ & $\begin{array}{l}0.07 \\
(0.76)\end{array}$ & $\begin{array}{r}-9,391.27 \\
(-0.20)\end{array}$ & $\begin{array}{r}-11,966.47 \\
(-0.26)\end{array}$ \\
\hline $\operatorname{Ln}\left(\right.$ Sales $\left._{i, t-1}\right)$ & $\begin{array}{l}0.41 \\
(7.48)^{* * *}\end{array}$ & $\begin{array}{l}0.41 \\
(7.43)^{* * *}\end{array}$ & & \\
\hline Sales $_{t-1}$ & & & $\begin{array}{l}27.73 \\
(4.21)^{* * *}\end{array}$ & $\begin{array}{l}27.45 \\
(4.14)^{* * *}\end{array}$ \\
\hline $\operatorname{Ln}\left(\right.$ MarketValue $\left._{i, t-1}\right)$ & $\begin{array}{l}0.28 \\
(5.03)^{* * *}\end{array}$ & $\begin{array}{l}0.28 \\
(5.02)^{* * *}\end{array}$ & & \\
\hline MarketValue $_{i, t-1}$ & & & $\begin{array}{l}10.97 \\
(2.48)^{* *}\end{array}$ & $\begin{array}{l}10.98 \\
(2.48)^{* *}\end{array}$ \\
\hline Industry fixed effects & YES & YES & YES & YES \\
\hline Calendar month fixed effects & YES & YES & YES & YES \\
\hline Year fixed effects & YES & YES & YES & YES \\
\hline$R^{2}$ & 0.42 & 0.42 & 0.11 & 0.11 \\
\hline Observations & 38,555 & 38,555 & 38,282 & 38,282 \\
\hline
\end{tabular}




\begin{tabular}{|c|c|c|c|c|}
\hline \multicolumn{5}{|c|}{ Panel C } \\
\hline & $\operatorname{Ln}\left(\right.$ Stock $\left._{i, m}\right)$ & $\operatorname{Ln}\left(\right.$ Stock $\left._{i, m}\right)$ & $\$$ Stock $_{i, m}$ & $\$$ Stock $_{i, m}$ \\
\hline NationalNegativity $_{[m-3, m-1]}$ & $\begin{array}{c}0.28 \\
(1.29)\end{array}$ & & $\begin{array}{r}109,540.90 \\
(1.62)\end{array}$ & \\
\hline NationalNegativity $_{[m-6, m-1]}$ & & $\begin{array}{l}0.73 \\
(2.45)^{* *}\end{array}$ & & $\begin{array}{l}237,768.9 \\
(2.53)^{* *}\end{array}$ \\
\hline Controls as in panel A & YES & YES & YES & YES \\
\hline Firm fixed effects & YES & YES & YES & YES \\
\hline Calendar month fixed effects & YES & YES & YES & YES \\
\hline Year fixed effects & YES & YES & YES & YES \\
\hline$R^{2}$ & 0.64 & 0.65 & 0.61 & 0.61 \\
\hline Observations & 7,040 & 7,040 & 7,040 & 7,040 \\
\hline \multicolumn{5}{|c|}{$\begin{array}{l}\text { Notes. In panels A and B, the dependent variable is either the log or the dollar value of each option grant made } \\
\text { to CEOs of firms covered in Execucomp during the modal month of each firm (defined in Table } 6 \text { ) as recorded in } \\
\text { the Thomson Reuters Insider Filings database during } 1996-2008 \text {. In panel C, the dependent variable is either the } \\
\text { log or the dollar value of each stock grant during the modal month of each firm. Regression models in panels A } \\
\text { and C include firm fixed effects, year fixed effects, calendar month fixed effects, as well as all firm characteris- } \\
\text { tics as in Table } 5 \text {. Panel B reports results from a specification as in Table 3. Standard errors are corrected for } \\
\text { heteroskedasticity and clustered at the firm-month level. All variables are described in Table } 1 \text {. } \\
{ }^{*} p<0.10 ; * * 0<0.05 ; * * * p<0.01 \text {. }\end{array}$} \\
\hline
\end{tabular}

show that the effects of negativity on the composition of CEO pay continue to be significant and similar to those documented in the main analysis in Table 3.

The top three panels in Table 8 contain results obtained using alternative measures of public attitudes toward CEO pay. In panel A we use the negativity measure based on the dictionary of Loughran and McDonald (2010). In panel B we use the state-level negativity of newspaper articles (i.e., those published in the state where the firm's headquarters are located) using our own dictionary. This adds cross-sectional variation to our measure of negativity. In panel $\mathrm{C}$ we calculate the negativity of press articles that cover options-based pay, excluding from the analysis all articles on CEO compensation that do not mention options, to focus on the most criticized component of pay during our sample. The results obtained using either of these alternative negativity measures are similar to those obtained in the main analysis in Table 3.

In panel $\mathrm{D}$ we show that our results are robust to including an indicator variable equal to one if the firm faced shareholder proposals on executive compensation in the prior year. Such initiatives may drive both press negativity and CEO compensation, because firms that are targets of shareholder proposals regarding CEO pay do not subsequently increase compensation as fast as other firms (Thomas and Martin 1998, Ertimur et al. 2011). ${ }^{15}$

Panel E presents results for all other top executives covered by Execucomp, excluding CEOs. The compensation of these individuals may also depend

\footnotetext{
${ }^{15}$ We thank Ernst Maug for sharing with us his shareholder proposal data for the period 1992 to 2005.
}

on the level of press negativity concerning executive pay, but likely to a lesser extent than the pay of the CEO, because lower level executives are less exposed to public scrutiny. For this analysis we compute the average compensation for non-CEO top officers of each firm and use it as a dependent variable in our main regression (as specified in Table 3). As expected, we find that for non-CEO executives, the impact of press negativity on various compensation components is of the same sign, but of lower magnitude, than for CEOs. For example, an increase of one standard deviation in the negativity of national press coverage toward executive compensation is followed by a decrease of $8 \%$ in the value of CEOs' options compensation but only by a decrease of $4 \%$ in the value of the other executives' options pay.

In panel $\mathrm{F}$ we include a National Bureau of Economic Research (NBER) recession indicator to account for the possibility that macroeconomic conditions unrelated to stock market valuations may drive both public opinion and CEO compensation. For instance, press negativity may be more prevalent in bad economic times, which may be followed by lower CEO pay. Our results do not change.

In panel $G$ we exclude data from the year 2006 because of the change from the prior year in the accounting of stock options and the reporting of pay variables by Execucomp. Alternatively, we exclude the years 2004 and 2005 when rule FAS 123(R) was passed but not yet implemented (not reported). Our results are robust to these exclusions.

To further analyze the economic significance of our results, in panel $\mathrm{H}$ we use dollar values of compensation. We drop the top and bottom $1 \%$ of pay observations, because results on CEO compensation are very 
Table 8 Robustness Checks: CEO Compensation and Press Negativity

\begin{tabular}{|c|c|c|c|c|c|c|}
\hline & $\begin{array}{c}\text { Total } \\
\text { Comp }_{i, t}\end{array}$ & Options $_{i, t}$ & $\begin{array}{l}\text { Salary+ } \\
\text { Bonus }_{i, t}\end{array}$ & $\begin{array}{l}\text { Other } \\
\text { Pay }_{i, t}\end{array}$ & Stock $_{i, t}$ & $\begin{array}{l}\text { Excess } \\
\text { Pay }_{i, t}\end{array}$ \\
\hline \multicolumn{7}{|c|}{ Panel A: Loughran and McDonald (2010) negativity } \\
\hline LMNegativity $_{t-1}$ & $\begin{array}{l}-0.07 \\
(-1.88)^{*}\end{array}$ & $\begin{array}{l}-1.14 \\
-9.69)^{* * *}\end{array}$ & $\begin{array}{l}0.23 \\
(7.94)^{* * *}\end{array}$ & $\begin{array}{l}0.29 \\
(5.27)^{* * *}\end{array}$ & $\begin{array}{l}0.93 \\
(9.16)^{* * *}\end{array}$ & $\begin{array}{l}-0.02 \\
(-0.57)\end{array}$ \\
\hline $\begin{array}{l}\text { Adjusted } R^{2} \\
\text { Observations }\end{array}$ & $\begin{array}{c}0.60 \\
19,658\end{array}$ & $\begin{array}{r}0.30 \\
19,668\end{array}$ & $\begin{array}{c}0.64 \\
19,923\end{array}$ & $\begin{array}{c}0.61 \\
19,709\end{array}$ & $\begin{array}{c}0.40 \\
19,908\end{array}$ & $\begin{array}{r}0.38 \\
16,324\end{array}$ \\
\hline \multicolumn{7}{|c|}{ Panel B: State level negativity } \\
\hline StateNegativity $_{j, t-1}$ & $\begin{array}{l}-0.05 \\
(-1.03)\end{array}$ & $\begin{array}{l}-1.08 \\
(-5.83)^{* * *}\end{array}$ & $\begin{array}{l}0.39 \\
(9.51)^{* * *}\end{array}$ & $\begin{array}{l}0.40 \\
(4.40)^{* * *}\end{array}$ & $\begin{array}{l}0.86 \\
(5.06)^{* * *}\end{array}$ & $\begin{array}{c}0.07 \\
(1.20)\end{array}$ \\
\hline Adjusted $R^{2}$ & 0.60 & 0.30 & 0.64 & 0.61 & 0.40 & 0.38 \\
\hline Observations & 19,658 & 19,668 & 19,923 & 19,709 & 19,908 & 16,324 \\
\hline \multicolumn{7}{|c|}{ Panel C: Negativity of press coverage of options-based pay } \\
\hline OptionsNegativity $_{t-1}$ & $\begin{array}{l}-0.12 \\
(-2.83)^{* * *}\end{array}$ & $\begin{array}{l}-0.94 \\
(-6.74)^{* * *}\end{array}$ & $\begin{array}{l}0.21 \\
(6.05)^{* * *}\end{array}$ & $\begin{array}{l}0.25 \\
(3.56)^{* * *}\end{array}$ & $\begin{array}{l}0.84 \\
(6.42)^{* * *}\end{array}$ & $\begin{array}{l}-0.05 \\
(-1.20)\end{array}$ \\
\hline Adjusted $R^{2}$ & 0.60 & 0.30 & 0.64 & 0.61 & 0.40 & 0.38 \\
\hline Observations & 19,658 & 19,668 & 19,923 & 19,709 & 19,908 & 16324 \\
\hline \multicolumn{7}{|c|}{ Panel D: Shareholder proposals on executive compensation } \\
\hline NationalNegativity $_{t-1}$ & $\begin{array}{l}-0.03 \\
(-0.69)\end{array}$ & $\begin{array}{l}-0.78 \\
(-4.47)^{* * *}\end{array}$ & $\begin{array}{c}0.50 \\
(11.70)^{* * *}\end{array}$ & $\begin{array}{l}0.46 \\
(5.32)^{* * *}\end{array}$ & $\begin{array}{l}0.93 \\
(5.67)^{* * *}\end{array}$ & $\begin{array}{l}-0.04 \\
(-0.76)\end{array}$ \\
\hline Adjusted $R^{2}$ & 0.58 & 0.30 & 0.63 & 0.60 & 0.40 & 0.37 \\
\hline Observations & 15,809 & 15,819 & 15,998 & 15,860 & 15,983 & 13971 \\
\hline \multicolumn{7}{|c|}{ Panel E: Other top level executives, excluding CEOs } \\
\hline NationalNegativity $_{t-1}$ & $\begin{array}{l}0.00 \\
(0.10)\end{array}$ & $\begin{array}{l}-0.38 \\
(-3.39)^{* * *}\end{array}$ & $\begin{array}{c}0.26 \\
(15.17)^{* * *}\end{array}$ & $\begin{array}{l}0.24 \\
(3.64)^{* * *}\end{array}$ & $\begin{array}{l}0.68 \\
(5.42)^{* * *}\end{array}$ & $\begin{array}{c}0.02 \\
(0.68)\end{array}$ \\
\hline Adjusted $R^{2}$ & 0.71 & 0.38 & 0.78 & 0.52 & 0.47 & 0.37 \\
\hline Observations & 19,805 & 19,807 & 19,919 & 19,805 & 19,919 & 16,455 \\
\hline \multicolumn{7}{|c|}{ Panel F: Including NBER recession indicator } \\
\hline NationalNegativity $_{t-1}$ & $\begin{array}{l}-0.08 \\
(-1.68)^{*}\end{array}$ & $\begin{array}{l}-0.61 \\
(-3.41)^{* * *}\end{array}$ & $\begin{array}{c}0.39 \\
(10.58)^{* * *}\end{array}$ & $\begin{array}{l}0.35 \\
(4.16)^{* * *}\end{array}$ & $\begin{array}{l}0.72 \\
(4.53)^{* * *}\end{array}$ & $\begin{array}{l}-0.05 \\
(-0.90)\end{array}$ \\
\hline Adjusted $R^{2}$ & 0.60 & 0.30 & 0.64 & 0.61 & 0.40 & 0.38 \\
\hline Observations & 19,658 & 19,668 & 19,923 & 19,709 & 19,908 & 16,324 \\
\hline \multicolumn{7}{|c|}{ Panel G: Excluding year 2006} \\
\hline NationalNegativity $_{t-1}$ & $\begin{array}{l}-0.05 \\
(-1.10)\end{array}$ & $\begin{array}{l}-1.12 \\
(-6.84)^{* * *}\end{array}$ & $\begin{array}{l}0.28 \\
(7.66)^{* * *}\end{array}$ & $\begin{array}{l}0.34 \\
(4.33)^{* * *}\end{array}$ & $\begin{array}{l}0.88 \\
(6.18)^{* * *}\end{array}$ & $\begin{array}{l}-0.01 \\
(-0.27)\end{array}$ \\
\hline Adjusted $R^{2}$ & 0.60 & 0.30 & 0.66 & 0.63 & 0.41 & 0.38 \\
\hline Observations & 18,252 & 18,259 & 18,493 & 18,289 & 18,483 & 15,076 \\
\hline \multicolumn{7}{|c|}{ Panel $\mathrm{H}$ : Using $\$$ values of pay (in thousands), top and bottom $1 \%$ excluded } \\
\hline NationalNegativity $_{t-1}$ & $\begin{array}{l}-977.99 \\
(-4.00)^{* * *}\end{array}$ & $\begin{array}{c}-1,190.48 \\
(-7.39)^{* * *}\end{array}$ & $\begin{array}{l}454.97 \\
(11.03)^{* * *}\end{array}$ & $\begin{array}{l}178.65 \\
(4.59)^{* * *}\end{array}$ & $\begin{array}{l}274.37 \\
(3.67)^{* * *}\end{array}$ & $\begin{array}{l}-1,308.64 \\
(-4.43)^{* * *}\end{array}$ \\
\hline Adjusted $R^{2}$ & 0.40 & 0.30 & 0.60 & 0.26 & 0.30 & 0.20 \\
\hline Observations & 18,948 & 19,057 & 19,157 & 18,772 & 19,312 & 15,747 \\
\hline \multicolumn{7}{|c|}{ Panel I: Using log values of pay (winsorized at $1 \%$ ) } \\
\hline NationalNegativity $_{t-1}$ & $\begin{array}{l}-0.08 \\
(-2.13)^{* * *}\end{array}$ & $\begin{array}{l}-0.73 \\
(-4.49)^{* * *}\end{array}$ & $\begin{array}{c}0.39 \\
(14.11)^{* * *}\end{array}$ & $\begin{array}{l}0.38 \\
(4.85)^{* * *}\end{array}$ & $\begin{array}{l}0.74 \\
(5.07)^{* * *}\end{array}$ & $\begin{array}{l}-0.03 \\
(-0.79)^{* *}\end{array}$ \\
\hline Adjusted $R^{2}$ & 0.64 & 0.30 & 0.67 & 0.61 & 0.40 & 0.37 \\
\hline Observations & 19,658 & 19,668 & 19,923 & 19,709 & 19,908 & 16,371 \\
\hline \multicolumn{7}{|c|}{ Panel J: Excess compensation } \\
\hline & $\begin{array}{c}\text { ExcessTotal } \text { Comp }_{i, t}\end{array}$ & $\begin{array}{l}\text { Excess } \\
\text { Options }_{i, t}\end{array}$ & $\begin{array}{l}\text { Excess } \\
\text { Salary }_{i, t}\end{array}$ & $\begin{array}{l}\text { Excess } \\
\text { Bonus }_{i, t}\end{array}$ & $\begin{array}{c}\text { Excess } \\
\text { OtherPay }_{i, t}\end{array}$ & $\begin{array}{l}\text { Excess } \\
\text { Stock }_{i, t}\end{array}$ \\
\hline NationalNegativity $_{t-1}$ & $\begin{array}{l}-0.01 \\
(-0.14)\end{array}$ & $\begin{array}{l}-0.51 \\
(-2.76)^{* * *}\end{array}$ & $\begin{array}{l}0.16 \\
(5.53)^{* * *}\end{array}$ & $\begin{array}{c}2.76 \\
(18.14)^{* * *}\end{array}$ & $\begin{array}{l}0.41 \\
(4.78)^{* * *}\end{array}$ & $\begin{array}{c}0.41 \\
(4.78)^{* * *}\end{array}$ \\
\hline Adjusted $R^{2}$ & 0.38 & 0.20 & 0.67 & 0.29 & 0.50 & 0.50 \\
\hline Observations & 16,324 & 16,269 & 16,400 & 16,400 & 16,290 & 16,290 \\
\hline
\end{tabular}

Notes. The table presents robustness checks for the estimated effects of the prior year's negativity on CEO pay. All regression models include the same controls as in panel $A$ of Table 3. Excess values of pay components in panel $E$ are calculated following the same procedure used by Core et al. (2008) to calculate excess total pay. Mean values of pay in panel F are computed for firms' top executives excluding the CEO. Standard errors are corrected for heteroskedasticity and clustered at the firm level. All variables are described in Table 1.

${ }^{*} p<0.10 ;{ }^{* *} p<0.05 ;{ }^{* * *} p<0.01$ 
sensitive to outliers (Guthrie et al. 2012). We find that increasing negativity by one standard deviation leads to a $\$ 0.13$ million decrease in options compensation, a $\$ 0.05$ million increase in salary and bonus, and a $\$ 0.03$ million increase in stock awards. These effects are economically significant, because in our sample the mean value of options, salary and bonuses, and stock awards received by a CEO in a given year are $\$ 1.9$ million, \$1.3 million, and \$0.7 million, respectively. Unlike in the main specification, in the dollar value regressions we also observe statistically significant effects of negativity on total as well as excess compensation, both of which decrease after increased press negativity. Because in the dollar-value specification observations from firms with high CEO pay influence the estimation more relative to the log-pay specification, this result suggests that these firms are particularly sensitive to public negativity. Our results are similar if we use log values of compensation that are first winsorized at the $1 \%$ level, instead of dropping the top and bottom $1 \%$ of observations (panel I). In panel $\mathrm{J}$ we compute the excess value of each pay component following the procedure that Core et al. (2008) used to calculate the excess value of total compensation and show that press negativity influences these excess values also; that is, high prior press negativity is followed by lower excess options pay and increased excess salary, bonuses, stocks, and other pay.

Hence, the results based on annual compensation data survive these robustness checks and suggest that firms adjust CEO pay by lowering the type of compensation that is highly contentious, i.e., stock options, while at the same time increasing less criticized types of pay. ${ }^{16}$

\subsection{Cross-Sectional Differences in Reputation Concerns and Reaction to Public Opinion}

In this section we investigate whether reputation concerns lead firms to change CEO pay composition in response to press negativity regarding executive compensation. The reputation hypothesis implies that firms, directors, or managers who face higher reputational costs if they anger the public will decrease more significantly the type of pay that is most criticized in the press. We present results based on the Thomson data, which allows for better identification than annual data, but similar results are obtained using Execucomp.

First, we split our sample by firm visibility using the sample median as a cutoff. Following Baker et al.

\footnotetext{
${ }^{16}$ We also check whether the same firms decrease option pay and concurrently increase other types of pay, that is, whether our results indicate a within-firm substitution effect from one type of pay to another. In unreported analyses, we find that the likelihood of a firm lowering options pay while at the same time increasing other compensation such as stock awards is significantly higher $(p<0.001)$ after more negative CEO pay press coverage.
}

(2002), we measure a firm's visibility by its size or analyst coverage. In addition, we use the existence of recent product safety concerns publicized in the media as a proxy for visibility because it is likely that firms facing such controversy are more publicly scrutinized. ${ }^{17}$ Analyst coverage data were obtained from I/B/E/S and calculated annually as the number of earnings per share analyst forecasts for each firm. The KLD database identifies each year whether a firm has recently been involved in controversy due to product safety concerns.

The results in panel A of Table 9 show, as predicted, that firms that are larger, have more analyst coverage, or have recently been involved in controversies regarding the safety of their products are those where CEO pay is most sensitive to press negativity (i.e., they have the highest decrease in option compensation). These firms are more publicly scrutinized and therefore have more at stake if they select a CEO pay package that the public deems inappropriate.

We then split the sample by the strength of the CEOs' reputation concerns. CEOs who are more entrenched arguably have less pressing career concerns, because they are more likely to retain their current job. Also, CEOs who consistently have conflicting relationships with the firm's employees may be less likely to worry about how they are perceived by others, including the public. The same is true for CEOs of firms engaging in accounting irregularities (i.e., intentional misstatements of financial information). Furthermore, younger CEOs should have stronger career concerns than CEOs close to retirement (Gibbons and Murphy 1992) and may be particularly interested in maintaining a good public image. Finally, CEOs working for firms in low reputation ("sin") industries such as tobacco or alcohol may also be less concerned about how they are perceived by the public.

Therefore, we measure the strength of the CEO's reputation concerns using the Bebchuk et al. (2009) entrenchment index; the number of corporate governance concerns recorded in the KLD database; the number of employee relations concerns, also obtained from KLD; the CEO's age (with 60 years as a threshold for retirement age as in Parrino 1997); the occurrence of accounting irregularities at a firm (as measured by Hennes et al. 2008); and a firm's classification to a sin industry as defined by Hong and Kacperczyk (2009). The results are shown in panel B

\footnotetext{
${ }^{17}$ A recent event provides evidence in this regard: on January 21, 2010, Toyota Motor Company issued a recall for 2.3 million vehicles because of gas pedal malfunctions in certain car models. In the following 10 days 704 articles in U.S. newspapers mentioned the firm. During the same 10 days a year earlier, when no recalls had recently occurred, only 486 articles referred to Toyota. Hence, the January 2010 recall was followed by a $45 \%$ increase in the press coverage of the company, suggesting the firm was more under public scrutiny as a result of this product safety issue.
} 


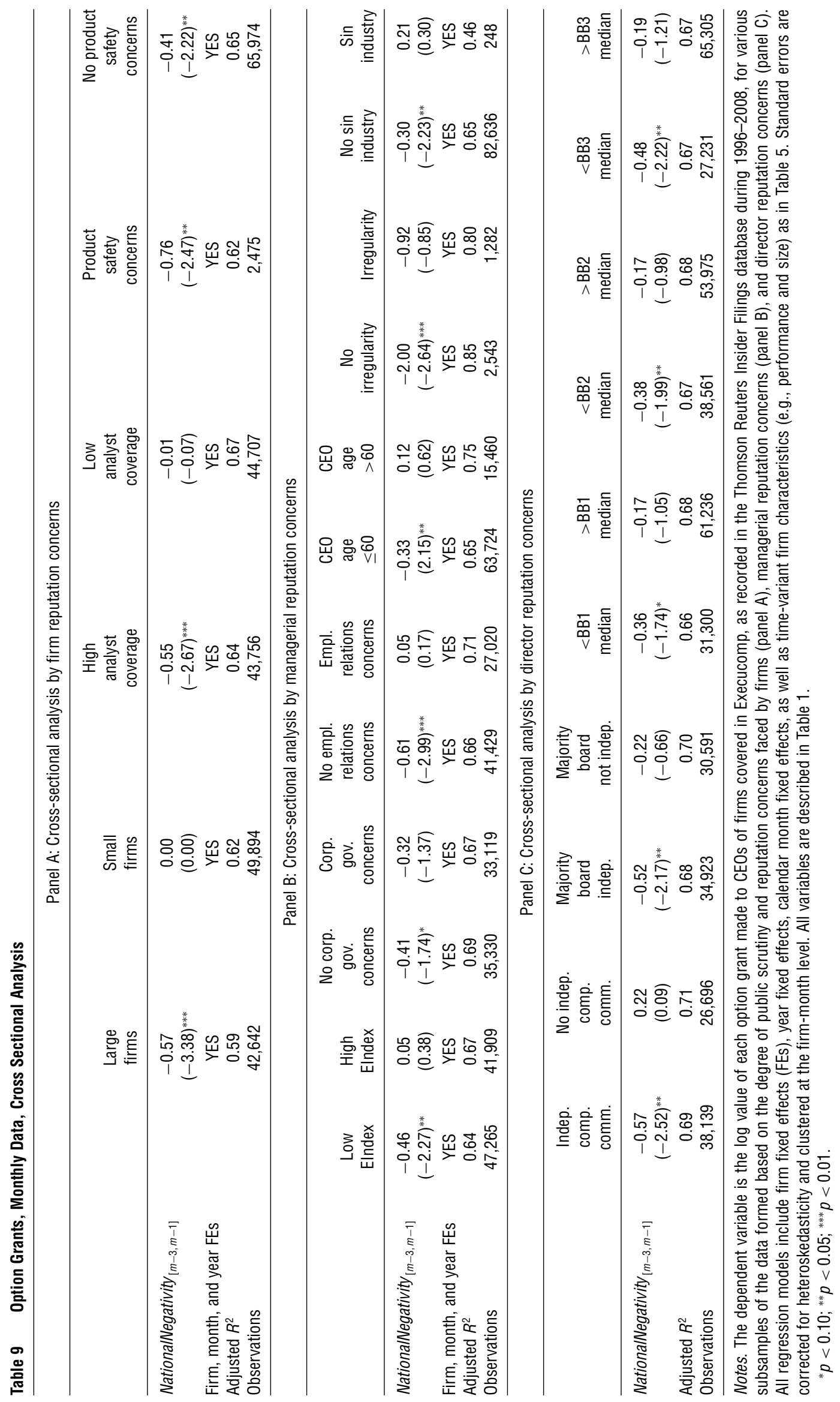


of Table 9. We find that the sensitivity of option compensation to public negativity regarding executive pay is indeed higher for firms where the management is less entrenched according to the Bebchuk et al. (2009) index, the KLD corporate governance concerns measure, the KLD employee relations measure, or the Hennes et al. (2008) accounting irregularity measure, as well as for firms with CEOs younger than the retirement age and for firms that do not operate in a sin industry.

Finally, we split the sample by the strength of directors' reputation concerns. The previous literature shows that corporate boards have a strong impact on CEO compensation (Core et al. 1999, Chhaochharia and Grinstein 2009). Therefore, it is important to investigate whether directors who care about their reputation amplify the impact of public opinion on CEO pay. Similar to our point regarding CEO reputation, we argue that more entrenched boards are less likely to worry about public opinion. Because director independence is generally associated with less entrenchment (Bebchuk and Weisbach 2001), we expect that firms with independent boards react more strongly to public criticism of CEO pay than firms with more entrenched boards. Also, because busy boards are weaker monitors (Fich and Shivdasani 2001), we expect firms with busy boards to react less to press negativity about CEO pay. We follow Ferris et al. (2003) and compute, using data from the Investor Responsibility Research Center (IRRC), several measures of board independence and board busyness for each firm and year: the average number of directorships per director for a given firm $(B B 1)$, the maximum number of directorships held by any one memberof a firm's board (BB2), the percentage of directors who hold three or more directorships (BB3), and two dummy variables (CCind and majind) that are equal to one if the majority of members in the compensation committee or the corporate board is independent and zero otherwise.

The results are presented in panel C of Table 9 . We find that the sensitivity of option compensation to press negativity about CEO pay is indeed higher for firms with less entrenched and less busy boards. Overall, the results of this section show that the effect of public opinion on executive compensation is stronger for firms, executives, and directors with stronger reputation concerns.

\subsection{Public Negativity and Pay-to-Performance Sensitivity}

Because public opinion can change CEO pay composition, it is possible that it will influence the strength of incentives faced by CEOs, which in turn impacts the magnitude of agency problems in the firm (Jensen and Meckling 1976) and ultimately firm value (Morgan and Poulsen 2001). We therefore analyze whether press negativity is related to subsequent PPS.
We use annual pay data from Execucomp, because the individual grant-level PPS that we could get from the Thomson data does not capture the overall steepness of incentives faced by a CEO at a particular point in time. Following Hartzell and Starks (2003), we measure the PPS of option awards as the Black-Scholes option $\delta$ multiplied by the number of shares granted and divided by the number of shares outstanding. We measure the PPS of stock awards as the number of shares granted divided by the number of shares outstanding. We then calculate the overall PPS as the sum of the PPS of options and stock grants as in Babenko (2009).

We estimate the effect of press negativity on subsequent PPS using Tobit specifications as in Hartzell and Starks (2003) to account for the truncated distribution of stock and option PPS values caused by the large number of zero-valued observations. We include the same covariates as in the main analysis in Table 3, control for the existing ownership of the CEO, and add lagged values of PPS to capture possible meanreversion effects similar to those documented by Core et al. (2008) for the level of total pay. The results are shown in Table 10. We find that increasing press negativity by one standard deviation decreases the PPS of option awards by $17 \%$ and increases that of stock awards by $14 \%$, while decreasing overall PPS by $15 \%$ ( $p<0.01$ for each of these effects).

As suggested by Jensen and Murphy (1990) and Hartzell and Starks (2003), lowering PPS may be detrimental to firm value. However, better-governed firms may be more likely to avoid the negative impact of press criticism on pay-for-performance sensitivity by taking more balanced actions. For example, well-governed firms may shift pay from options to restricted stock, whereas poorly governed ones may shift pay from options to salary. The latter firms will therefore lower PPS more and offer weaker incentives to their CEOs. The Tobit regression in panel B of Table 10 suggests that this is indeed the case. The negative impact of public opinion on pay-for-performance sensitivity is less pronounced for well-governed firms.

\subsection{What to Expect Next?}

As discussed earlier and shown in Figure 2, bonuses became the most criticized type of CEO pay in 2009. This suggests that starting in 2009 there might have been a shift away from bonus to other types of pay, akin to the shift away from options that we document for the period 1992-2008. Because only observations for 2009 were available at the time this paper was written, we compute changes in different components of CEO pay between 2008 and 2009. We find that relative to 2008, in 2009 the average salary received by CEOs of the 1,757 firms reported in Execucomp increased by $1 \%$. Option grants decreased by $9 \%$, 
Change in Incentives

\begin{tabular}{|c|c|c|c|}
\hline \multicolumn{4}{|c|}{ Panel A } \\
\hline & OptionSensitivity $_{t}$ & StockSensitivity $_{t}$ & OptStockSensitivity $_{t}$ \\
\hline NationalNegativity $_{t-1}$ & $\begin{array}{l}-1.50 \\
(-4.90)^{* * *}\end{array}$ & $\begin{array}{c}1.28 \\
(23.39)^{* * *}\end{array}$ & $\begin{array}{l}-1.38 \\
(-3.47)^{* * *}\end{array}$ \\
\hline Sensitivity $_{t-1}$ & $\begin{array}{l}0.23 \\
(9.51)^{* * *}\end{array}$ & $\begin{array}{c}0.25 \\
(46.54)^{* * * *}\end{array}$ & $\begin{array}{l}0.16 \\
(5.55)^{* * *}\end{array}$ \\
\hline Ownership $_{t-1}$ & $\begin{array}{l}-0.01 \\
(-4.66)^{* * *}\end{array}$ & $\begin{array}{c}-0.01 \\
(-12.32)^{* * *}\end{array}$ & $\begin{array}{l}-0.01 \\
(-4.57)^{* * *}\end{array}$ \\
\hline StockRet $_{t-1}$ & $\begin{array}{l}0.27 \\
(3.01)^{* * *}\end{array}$ & $\begin{array}{l}-0.23 \\
(-7.43)^{* * *}\end{array}$ & $\begin{array}{c}0.15 \\
(1.54)\end{array}$ \\
\hline$R O A_{t-1}$ & $\begin{array}{c}0.07 \\
(0.11)\end{array}$ & $\begin{array}{c}-3.57 \\
(-17.53)^{* * *}\end{array}$ & $\begin{array}{l}-2.77 \\
(-2.48)^{* *}\end{array}$ \\
\hline SalesGrowth $_{t-1}$ & $\begin{array}{l}0.77 \\
(3.90)^{* * *}\end{array}$ & $\begin{array}{c}0.14 \\
(1.46)\end{array}$ & $\begin{array}{l}0.61 \\
(2.13)^{* *}\end{array}$ \\
\hline Sales $_{t-1}$ & $\begin{array}{l}-0.42 \\
(-5.82)^{* * *}\end{array}$ & $\begin{array}{c}0.97 \\
(102.79)^{* * *}\end{array}$ & $\begin{array}{l}-0.01 \\
(-0.07)\end{array}$ \\
\hline MarketValue $_{t-1}$ & $\begin{array}{l}-0.48 \\
(-6.85)^{* * *}\end{array}$ & $\begin{array}{c}-0.48 \\
(-52.75)^{* * *}\end{array}$ & $\begin{array}{l}-0.51 \\
(-5.65)^{* * *}\end{array}$ \\
\hline Volatility $_{t-1}$ & $\begin{array}{l}2.68 \\
(7.12)^{* * *}\end{array}$ & $\begin{array}{l}-1.09 \\
(-6.11)^{* * *}\end{array}$ & $\begin{array}{l}2.39 \\
(6.58)^{* * *}\end{array}$ \\
\hline Eindex $_{t-1}$ & $\begin{array}{l}0.11 \\
(2.80)^{* * *}\end{array}$ & $\begin{array}{c}0.46 \\
(25.48)^{* * *}\end{array}$ & $\begin{array}{l}0.19 \\
(3.24)^{* * *}\end{array}$ \\
\hline$S P 500 R E T_{t-1}$ & $\begin{array}{c}0.26 \\
(1.22)\end{array}$ & $\begin{array}{l}1.20 \\
(7.75)^{* * *}\end{array}$ & $\begin{array}{l}0.70 \\
(2.23)^{* *}\end{array}$ \\
\hline CEOIsUnder60 ${ }_{t}$ & $\begin{array}{l}0.68 \\
(7.18)^{* * *}\end{array}$ & $\begin{array}{c}0.39 \\
(5.89)^{* * *}\end{array}$ & $\begin{array}{l}0.83 \\
(6.05)^{* * *}\end{array}$ \\
\hline Year $_{t}$ & $\begin{array}{l}-0.06 \\
(-5.66)^{* * *}\end{array}$ & $\begin{array}{c}0.35 \\
(7,901.34)^{* * *}\end{array}$ & $\begin{array}{l}0.09 \\
(5.34)^{* * *}\end{array}$ \\
\hline PseudoR ${ }^{2}$ & 0.08 & 0.04 & 0.02 \\
\hline Observations & 19,106 & 19,106 & 19,106 \\
\hline
\end{tabular}

\begin{tabular}{|c|c|c|c|c|c|c|}
\hline \multicolumn{7}{|c|}{ Panel B: Cross-sectional analysis by corporate governance quality; same controls as in panel A } \\
\hline OptStockSensitivity $_{t}$ & $\begin{array}{l}\text { Low } \\
\text { Elndex }\end{array}$ & $\begin{array}{l}\text { High } \\
\text { Elndex }\end{array}$ & $\begin{array}{l}\text { No corp. } \\
\text { governance } \\
\text { concerns }\end{array}$ & $\begin{array}{c}\text { Corp. } \\
\text { governance } \\
\text { concerns }\end{array}$ & $\begin{array}{l}\text { No employee } \\
\text { relations } \\
\text { concerns }\end{array}$ & $\begin{array}{l}\text { Employee } \\
\text { relations } \\
\text { concerns }\end{array}$ \\
\hline ationalNegativity $_{t-1}$ & $\begin{array}{l}-0.90 \\
(-3.16)^{* * *}\end{array}$ & $\begin{array}{l}-1.05 \\
(-4.55)^{* * *}\end{array}$ & $\begin{array}{l}-0.54 \\
(-2.23)^{* *}\end{array}$ & $\begin{array}{l}-1.06 \\
(-3.50)^{* * *}\end{array}$ & $\begin{array}{c}-0.43 \\
(-1.84)^{*}\end{array}$ & $\begin{array}{c}-0.82 \\
(-2.37)^{* *}\end{array}$ \\
\hline $\begin{array}{l}\text { Pseudo- } R^{2} \\
\text { Observations }\end{array}$ & $\begin{array}{c}0.05 \\
9,273\end{array}$ & $\begin{array}{c}0.04 \\
9,714\end{array}$ & & & $\begin{array}{r}0.05 \\
7,732\end{array}$ & \\
\hline \multicolumn{7}{|c|}{ 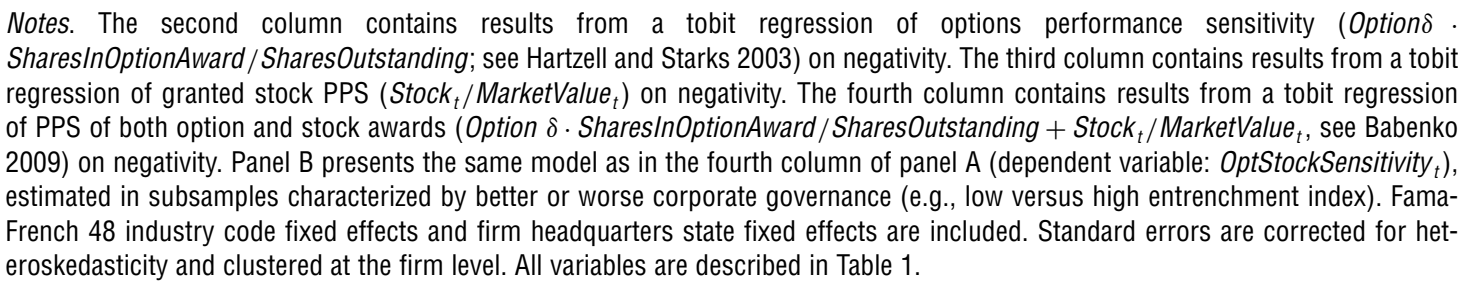 } \\
\hline
\end{tabular}$$
{ }^{*} p<0.10 ;{ }^{* *} p<0.05 ;{ }^{* * *} p<0.01 \text {. }
$$

and stock grants increased by $20 \%$. Most importantly, the average bonus payment decreased by $17 \%$. This result is consistent with our hypothesis that firms shift compensation away from the type that is most criticized by the public - specifically, options until 2008 and bonuses in 2009. ${ }^{18}$

${ }^{18}$ It seems that public outrage regarding the extravagant bonuses paid by AIG in early 2009 quickly induced Congress to discuss
Also, it is possible that recent global public outrage regarding income inequality, specifically the "Occupy Wall Street" movement (which started as this paper

introducing further regulation of executive pay. On March 18, 2009, the National Journal published the following quote of the Senate's Finance Committee chair, Max Baucus: "We believe that [preparing legislation to impose steep excise taxes on bonuses] is the right thing to do. American taxpayers are justifiably outraged at what AIG has done" (Cohn 2009, p. 1). 
entered the final publication stage), may put further constraints on executive compensation. For example, it may induce the U.S. Securities and Exchange Commission to speed up the adoption of a rule proposed in the 2010 Dodd-Frank Wall Street Reform and Consumer Protection Act that would require companies to disclose the ratio of the CEO's annual total compensation to the median annual total compensation of all other employees (Beales et al. 2011). It remains to be seen, however, if stricter requirements regarding CEO pay disclosure will have a significant impact on the firms' choice of executive compensation schemes.

\section{Conclusions}

This paper investigates whether public opinion influences the level and composition of executive pay. We find that after increased press negativity about CEO compensation, firms lower the type of pay that is most criticized in the press and increase less contentious types of pay, with the net effect of lowering pay-to-performance sensitivity. The avoidance of the most controversial pay type (i.e., options during 1992-2008) is more pronounced when firms, CEOs, or boards have stronger reputation concerns. The effects we document here provide a lower bound on the influence of public opinion on CEO pay. Neither Execucomp nor Thomson Reuters Insider Filings capture the entire compensation received by CEOs, because a nontrivial part of this compensation is provided in hidden forms such as perquisites and severance pay (Yermack 2006). It is likely that compensation can be shifted from types of pay the public disapproves of to one of these hidden types with little public awareness (Weisbach 2007), but because of data limitations we can not identify such transfers.

The evidence documented here indicates that firms and their leaders perceive that taking actions subject to public outrage can have large reputation costs. Additionally, it is possible that public outrage increases the likelihood of new regulation (Herbst 1998, Culpepper 2010), which may cause firms to act preemptively to avoid further legal constraints on their choices. In the context of executive compensation, our results suggest that public opinion induces firms to change the structure of managerial incentives, and therefore it may influence executive decisions about project or financing choice and ultimately impact firm value.

\section{Acknowledgments}

The authors are grateful to Brad Barber; two anonymous referees; Ingolf Dittmann; Alexander Dyck; Fabrizio Ferri; Campbell Harvey; Koon Boon Kee; Alexander Ljungqvist; Tim Loughran; Ernst Maug; Stefan Ruenzi; Martin Weber; Jun Yang; David Yermack; participants at the 2009 Midwest Finance Association, European Financial Management Association (FMA), and German and Swiss Finance Association meetings; and the 2010 American Finance Association, Financial Intermediation Research Society, National Bureau of Economic Research, and FMA meetings; and seminar participants at the University of Mannheim. All remaining errors are the authors' responsibility. An earlier version of this paper was circulated as "Is Executive Compensation Shaped by Public Attitudes?" Camelia Kuhnen gratefully acknowledges financial support from the Zell Center for Risk Research.

\begin{tabular}{|c|c|c|c|c|}
\hline abuse & cry & handsome & outcried & shock \\
\hline acrimonious & curb & hard & outcry & sizeable \\
\hline aggressive & cut & heftier & outlandish & skyrocket \\
\hline aggrieve & cynicism & hide & outpace & slash \\
\hline alarm & debate & high & outrage & slashing \\
\hline anger & defend & huge & outsize & snag \\
\hline angry & demand & hurt & overhead & soar \\
\hline arrogant & dent & illegal & overpaid & sock \\
\hline astounding & deserve & improper & pamper & spiral \\
\hline attack & destroy & indecent & pay-cutting & stagger \\
\hline avarice & devastate & indefensible & payday & stupefying \\
\hline backdate & disconnect & inept & penalize & suffer \\
\hline balloon & discontent & inflationary & perk & suit \\
\hline battle & disgruntle & infuriate & perquisite & super-size \\
\hline bestow & dispute & irate & phony & surge \\
\hline betrayal & disregard & irksome & pocket & swell \\
\hline big & dizzy & irresponsible & porker & tenuous \\
\hline bigbucks & dole & issue & pressure & threat \\
\hline bigmoney & doubt & justifiable & probe & too \\
\hline bigpackages & dubious & lag & problem & trial \\
\hline bigpay & egregious & lavish & protest & trouble \\
\hline
\end{tabular}




\section{Appendix A (Continued)}

\begin{tabular}{lllll}
\hline bigpaychecks & embarrass & lawsuit & pull & turn \\
bigsalary & enjoy & layoff & pump & turndown \\
bloat & enrich & legal & question & unconscionable \\
bonanza & entitle & lie & rage & undeserve \\
boom & entrench & litigation & record & uneven \\
boost & equitable & loath & reduce & unfair \\
breathing & escalate & loot & reform & unhappy \\
camouflage & ethical & loss-ridden & refuse & unjustifiable \\
chide & exaggerate & lucrative & repulsive & unthinkable \\
colossal & excess & lying & resist & unusual \\
compensation-inflation & extravagance & mad & restrain & uproar \\
complain & failure & manipulate & revolution & vocal \\
concern & fair & massive & rich & weaken \\
conflict & fat & me-first & robber & whack \\
controversial & fat-cat & mercenarily & rock & whopper \\
cost & fire & mislead & rubber & windfall \\
court & flunk & moral & run & wring \\
cried & fodder & murky & sacrifice & wrong \\
criminal & generous & negative & scandal & \\
crises & gigantic & nervous & scrutiny & \\
crisis & greed & odious & shame & \\
criticism & gross & opposition & sharp & \\
\hline
\end{tabular}

Note. Grammatical variations are not included for brevity.

\section{Appendix B. Words Used to Calculate the Frequency of Mentions of Individual Components of Executive Compensation}

\begin{tabular}{ll}
\hline Pay component & \multicolumn{1}{c}{ Keywords } \\
\hline Salary & salary \\
Bonus & bonus \\
Options & option \\
& backdating \\
Stock & share \\
& restricted stock \\
& stock grant \\
& preferred stock \\
& stock award \\
& stock bonus \\
\hline
\end{tabular}

Note. Grammatical variations are not included for brevity.

\section{References}

Anderson, G. T. 2003. The next outrage is CEO pay? CNN Money (April 24), http://money.ccn.com/2003/04/23/pf/investing/ CEOs_nextoutrage/.

Arellano, M., S. Bond. 1991. Some tests of specification for panel data: Monte Carlo evidence and an application to employment equations. Rev. Econom. Stud. 58(2) 277-297.

Babenko, I. 2009. Share repurchases and pay-performance sensitivity of employee compensation contracts. J. Finance 64(1) 117-150.

Baker, G., M. Jensen, K. J. Murphy. 1988. Compensation and incentives: Practice vs. theory. J. Finance 43(3) 593-616.

Baker, H. K., J. R. Nofsinger, D. G. Weaver. 2002. International crosslisting and visibility. J. Financial Quant. Anal. 37(3) 495-521.
Beales, R., E. Hadas, P. T. Larsen, A. Currie. 2011. A manifesto for Wall Street protesters. New York Times (October 6), http://www .nytimes.com/2011/10/06/business/a-manifesto-for-wall-street -protesters.html.

Bebchuk, L., J. Fried. 2004. Pay Without Performance. Harvard University Press, Cambridge, MA.

Bebchuk, L., M. Weisbach. 2001. The state of corporate governance research. Rev. Financial Stud. 23(3) 939-961.

Bebchuk, L., A. Cohen, A. Ferrell. 2009. What matters in corporate governance? Rev. Financial Stud. 22(2) 783-827.

Bebchuk, L., J. Fried, D. Walker. 2002. Managerial power and rent extraction in the design of executive compensation. Univ. Chicago Law Rev. 69(3) 751-846.

Beck, R. M. Fordahl. 2009. CEO pay plunged in 2008. Huffington Post (May 1), http://www.huffingtonpost.com/2009/05/ 01/ceo-pay-plunged-in-2008_n_194374.html.

Blundell, R., S. Bond. 1998. Initial conditions and moment restrictions in dynamic panel data models. J. Econometrics 87(1) $115-143$.

Byrne, J. A. 1991. Are CEOs paid too much? Business Week (May 6) 1.

Carter, M. E., L. J. Lynch, I. Tuna. 2007. The role of accounting in the design of CEO equity compensation. Accounting Rev. 82(2) 327-357.

Chhaochharia, V., J. Grinstein. 2009. CEO compensation and board structure. J. Finance 64(1) 231-261.

Cohn, P. 2009. Congress moves quickly to punish AIG. National J. (March 18) 1.

Core, J., R. Holthausen, D. Larcker. 1999. Corporate governance, chief executive officer compensation, and firm performance. J. Financial Econom. 51(3) 371-406.

Core, J. E., W. Guay, D. F. Larcker. 2008. The power of the pen and executive compensation. J. Financial Econom. 88(1) 1-25.

Culpepper, P. D. 2010. Quiet Politics and Business Power. Cambridge University Press, Cambridge, UK.

Dennis, B., D. Cho. 2009. Rage at AIG swells as bonuses go out. Washington Post (March 17) A01.

Dvorak, P. 2009. Executive salaries remain under pressure in '09. Wall Street Journal (April 3), http://online.wsj.com/article/ SB123871034320684235.html. 
Dyck, A., L. Zingales. 2002. The corporate governance role of the media. The Right to Tell: The Role of the Media in Development. The World Bank, Washington, DC, 107-141.

Dyck, A., N. Volchkova, L. Zingales. 2008. The corporate governance role of the media: Evidence from Russia. J. Finance 63(3) 1093-1135.

Ertimur, Y., F. Ferri, V. Muslu. 2011. Shareholder activism and CEO pay. Rev. Financial Stud. 24(2) 535-592.

Fama, E., K. French. 1997. Industry costs of equity. J. Financial Econom. 43(2) 153-193.

Farrell, G. 2009. Public anger to rein in top Goldman bonuses. Financial Times (October 15), http://www.ft.com/cms/s/0/ 46916a36-b9d4-11de-a747-00144feab49a.html\#axzz1kRgALtHt.

Ferris, S. P., M. Jagannathan, A. C. Pritchard. 2003. Too busy to mind the business? Monitoring by directors with multiple board appointments. J. Finance 58(3) 1087-1111.

Fich, E. M., A. Shivdasani. 2001. Are busy boards effective monitors? J. Finance 61(2) 689-724.

Gibbons, R., K. J. Murphy. 1992. Optimal incentive contracts in the presence of career concerns: Theory and evidence. J. Political Econom. 100(2) 468-505.

Gompers, P., J. Ishii, A. Metrick. 2003. Corporate governance and equity prices. Quart. J. Econom. 118(1) 107-155.

Guthrie, K., J. Sokolowsky, K.-M. Wan. 2012. CEO compensation and board structure revisited. J. Finance 67(3) 1149-1168.

Hartzell, J. C., L. T. Starks. 2003. Institutional investors and executive compensation. J. Finance 58(6) 2351-2374.

Hayes, R. M., M. Lemmon, M. Qiu. 2012. Stock options and managerial incentives for risk-taking: Evidence from FAS 123R. J. Financial Econom. Forthcoming.

Hennes, K. M., A. J. Leone, B. P. Miller. 2008. The importance of distinguishing errors from irregularities in restatement research: The case of restatements and CEO/CFO turnover. Accounting Rev. 83(6) 1487-1520.

Herbst, S. 1998. Reading Public Opinon: How Political Actors View the Democratic Process. University of Chicago Press, Chicago.

Holmstrom, B., S. Kaplan. 2003. The state of U.S. corporate governance: What's right and what's wrong? J. Appl. Corporate Finance 15(3) 8-20.

Hong, H., M. Kacperczyk. 2009. The price of sin: The effects of social norms on markets. J. Financial Econom. 93(1) 15-36.

Jensen, M., W. Meckling. 1976. Theory of the firm: Managerial behavior, agency costs, and ownership structure. J. Financial Econom. 3(4) 360-395.

Jensen, M. C., K. J. Murphy. 1990. Performance pay and topmanagement incentives. J. Political Econom. 98(2) 225-264.

Joe, J. R., H. Louis, D. Robinson. 2009. Managers' and investors' responses to media exposure of board ineffectiveness. J. Financial Quant. Anal. 44(3) 579-605.

Johnson, M. F., S. Porter, M. B. Shackell. 1997. Stakeholder pressure and the structure of executive compensation. Working paper, Michigan State University, East Lansing.

Klein, D., E. Maug. 2009. How do executives exercise their stock options? Working paper, University of Mannheim, Mannheim, Germany.

Kuhnen, C. M., J. Zwiebel. 2007. Executive pay, hidden compensation and managerial entrenchment. Working paper, Northwestern University, Evanston, IL.

$\mathrm{Li}$, F. 2010. The determinants and information content of the forward-looking statements in corporate filings-A Naive
Bayesian machine learning approach. J. Accounting Res. 48(5) 1049-1102.

Loughran, T., B. McDonald. 2010. When is a liability not a liability? Textual analysis, dictionaries, and 10-Ks. J. Finance 66(1) 35-65.

Lublin, J. S. 2005. A few share the wealth. Wall Street Journal (December 12) 1, section B, column 3.

McCall, L. 2003. Do they know and do they care? Americans' awareness of rising inequality. Working paper, Rutgers University, New Brunswick, NJ.

Michalisin, M. D., D. M. Kline, R. D. Smith. 2000. Intangible strategic assets and firm performance: A multi-industry study of the resource based view. J. Bus. Strategies 17(2) 93-117.

Milgrom, P., J. Roberts. 1982. Predation, reputation and entry deterrence. J. Econom. Theory 27(2) 280-312.

Miller, G. S. 2006. The press as a watchdog for accounting fraud. J. Accounting Res. 44(5) 1001-1033.

Morgan, A. G., A. B. Poulsen. 2001. Linking pay to performanceCompensation proposals in the S\&P 500. J. Financial Econom. 62(3) 489-523.

Murphy, K. J. 1999. Executive compensation. O. Ashenfelter, D. E. Card, eds. Handbook of Labor Economics, Vol. 3. Elsevier Science B.V., Amsterdam, The Netherlands, 2485-2563.

Niven, D. 2001. Bias in the news. Internat. J. Press Politics 6(3) 31-46.

Page, B., L. Jacobs. 2009. Class War? What Americans Really Think About Economic Inequality. University of Chicago Press, Chicago.

Parrino, R. 1997. CEO turnover and outside succession. J. Financial Econom. 46(2) 165-197.

Pennebaker, J. W., R. J. Both, M. E. Francis. 2007. Linguistic inquiry and word count (LIWC2007): A text analysis program. Retrieved January 18, 2008, http://www.LIWC.net.

Roberts, P., G. Dowling. 2002. Corporate reputation and sustained superior financial performance. Strategic Management J. 23(12) 1077-1093.

Rose, N., C. Wolfram. 2002. Regulating executive pay: Using the tax code to influence chief executive officer compensation. J. Labor Econom. 20(S2) S138-S175.

Tetlock, P. C. 2007. Giving content to investor sentiment: The role of media in the stock market. J. Finance 62(3) 1139-1168.

Tetlock, P. C., M. Saar-Tsechansky, S. Macskassy. 2008. More than words: Quantifying language to measure firms' fundamentals. J. Finance 63(3) 1437-1467.

Thomas, R. S., K. J. Martin. 1998. The effect of shareholder proposals on executive compensation. Univ. Cincinnati Law Rev. 67(4) 1021-1081.

Walker, D. I. 2009. Evolving executive equity compensation and the limits of optimal contracting. Working Paper 09-46, School of Law, New York University, New York.

Weisbach, M. S. 2007. Optimal executive compensation versus managerial power: A review of Lucian Bebchuk and Jesse Fried's pay without performance: The unfulfilled promise of executive compensation. J. Econom. Literature 45(2) 419-428.

Welsh, I. 2009. The AIG bonus clawback bill won't workHere's what will. Huffington Post (March 23), http://www .huffingtonpost.com/ian-welsh/the-aig-bonus-clawback-bi_b _177881.html.

Wintoki, M. B., J. S. Linck, J. M. Netter. 2012. Endogeneity and the dynamics of corporate governance. J. Financial Econom. Forthcoming.

Yermack, D. 2006. Flights of fancy: Corporate jets, CEO perquisites, and inferior shareholder returns. J. Financial Econom. 80(1) 211-242. 